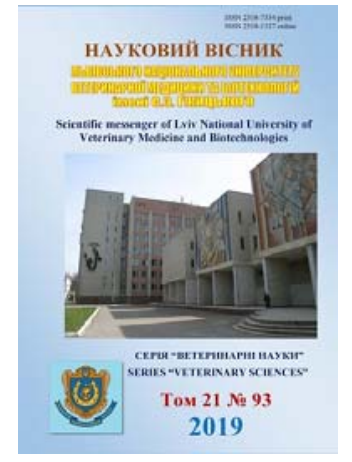

\author{
Науковий вісник Аьвівського національного університету \\ ветеринарної медицини та біотехнологій імені С.3. Гжицького. \\ Серія: Ветеринарні науки \\ Scientific Messenger of Lviv National University \\ of Veterinary Medicine and Biotechnologies. \\ Series: Veterinary sciences
}

ISSN 2518-7554 print ISSN 2518-1327 online doi: $10.32718 /$ nvlvet9314

http://nvlvet.com.ua

UDC 618.46:611.031.8:636.2.1

\title{
Placental barrier permeability to Cadmium and Plumbum during cow pregnancy and at the foaling time of mares
}

\author{
H. Kalynovskyi ${ }^{1}$, L. Yevtukh ${ }^{1}$, V. Shnaider ${ }^{1}$, V. Zakharin ${ }^{1}$, V. Karpiuk ${ }^{1}$, M. Omelianenko ${ }^{2}$ \\ ${ }^{1}$ Zhytomyr National Agroecological University, Zhytomyr, Ukraine \\ ${ }^{2}$ National University of Life and Environmental Science of Ukraine, Kyiv, Ukraine
}

Article info

Received 24.01.2019

Received in revised form 11.03 .2019

Accepted 12.03.2019

Zhytomyr National Agroecological University, Korolyova Str., 39, Zhytomyr, 10025, Ukraine Tel.: +38-067-478-37-17 E-mail: zakharin35@ukr.net

National University of Life and Environmental Sciences of Ukraine, Heroyiv Oborony Str., 15 , Kyiv, 03041, Ukraine.
Kalynovskyi, H., Yevtukh, L., Shnaider, V., Zakharin, V., Karpiuk, V., \& Omelianenko, M. (2019). Placental barrier permeability to cadmium and plumbum during cow pregnancy and at the foaling time of mares. Scientific Messenger of Lviv National University of Veterinary Medicine and Biotechnologies. Series: Veterinary sciences, 21(93), 74-87. doi: 10.32718/nvlvet 9314

The paper explores placental barrier permeability to Cadmium $(\mathrm{Cd})$ and Plumbum $(\mathrm{Pb})$ in cows in the dynamics of their pregnancy in the direction 'maternal blood $(M B) \rightarrow$ maternal placental compartment $(M P C) \rightarrow$ fetal placental compartment $(F P C) \rightarrow$ the umbilical cord (UC) $\rightarrow$ fetal liver $(F L) \rightarrow$ amniotic $(A M F)$ and allantoic $(A L F)$ fluid' and during parturition in relatively clean and contaminated with radioactive nuclides environments, with the injection of tissue medication fetoplacentat in the dry off time, and feeding with a mixture of saponite and sulphur supplementation in rations; in mares at the foaling time in the direction 'maternal blood $(\mathrm{MBm}) \rightarrow$ the fetal placental compartment of a mare (FPCm) $\rightarrow$ the umbilical cord of a foal (UCf) $\rightarrow$ the foal's liver (FLf) $\rightarrow$ amniotic (AMFf) and allantoic (ALFf) fluid $\rightarrow$ the allantoic membrane of a foal (ALMf): The age of the fetus during pregnancy was established by anatomical parameters, whereas $\mathrm{Pb}$ and Cd levels in blood and substrates were measured by the method of atomic absorption spectrophotometry (GOST 30170896). The MPC (caruncle) and FPC (cotyledon) were analyzed separately. Their barrier function in relation to $\mathrm{Pb}$ and $\mathrm{Cd}$ was performed at its full extent in 4-5 months of pregnancy and coincided with the highest concentration in the fetal liver. Wharton's jelly absorbed $\mathrm{Cd}$ in 3-4 months of gestation. With the approach of calving, $\mathrm{Pb}$ and $\mathrm{Cd}$ levels decreased in the amniotic fluid and increased in the allantoic fluid. Under the influence of fetoplacentat in MPC and FPC Cd accumulated better in AMF and ALF, whereas its levels were lower in the cortical mucus of the cervix. Pb deposited in equal concentrations in MPC of all the cows $(0.46 \pm 0.18 \mu \mathrm{g} / \mathrm{kg}$ in the contaminated environment and $0.47 \pm 0.17 \mu \mathrm{g} / \mathrm{kg}$ in the relatively clean environment). In the relatively clean environment its levels in ALF were lower in 8 times $(0.62 \pm 0.16 \mu \mathrm{g} / \mathrm{kg}$ and $0.08 \pm 0.04 \mu \mathrm{g} / \mathrm{kg})$ and 26 times lower in $A M F(0.52 \pm 0.07 \mu \mathrm{g} / \mathrm{kg}$ and $0.02 \pm 0.002 \mu \mathrm{g} / \mathrm{kg})$, whereas Pb concentration in the cortical mucus of the cervix was 17 times lower $(0.06 \pm 0.03 \mu \mathrm{g} / \mathrm{kg})$ than that in the contaminated environment, $(1.01 \pm 0.28 \mu \mathrm{g} / \mathrm{kg})$. Pb transited from MPC $(0.46 \pm 0.18 \mu \mathrm{g} / \mathrm{kg})$ to $F P C(0.51 \pm$ $0.19 \mu \mathrm{g} / \mathrm{kg}$ ), deposited in the internal environment of the uterus wherefrom it was absorbed by the cortical mucus of the cervix $(1.01 \pm 0.28 \mu \mathrm{g} / \mathrm{kg})$. While transiting through the fetal body Pb accumulated in amniotic $(0.52 \pm 0.07 \mu \mathrm{g} / \mathrm{kg})$ and allantoic fluid $(0.62 \pm 0.16 \mu \mathrm{g} / \mathrm{kg})$. Mineral supplement in rations led to a weakened barrier function of MPC $(0.23 \pm 0.14 \mu \mathrm{g} / \mathrm{kg})$, a two-fold increase of Pb in FPC $(0.47 \pm 0.11 \mu \mathrm{g} / \mathrm{kg})$, whereas in the allantoic $(0.16 \pm 0.05 \mu \mathrm{g} / \mathrm{kg})$ and amniotic $(0.38 \pm 0.10 \mu \mathrm{g} / \mathrm{kg})$ fluid Pb concentration was lower when compared to the control group $(0.62 \pm 0.16 \mu \mathrm{g} / \mathrm{kg} ; P<0.05$ i $0.52 \pm 0.07 \mu \mathrm{g} / \mathrm{kg} ; P<0.05$, respectively). $\mathrm{Pb}$ deposited in the cortical mucus of the cervix $(2.47 \pm 0.26 \mu \mathrm{g} / \mathrm{kg} ; P<0.001)$. With the injection of fetoplacentat the barrier function of MPC became weaker $(0.06 \pm 0.01 \mu \mathrm{g} / \mathrm{kg})$ than that of the control group $(0.46 \pm 0.17 \mu \mathrm{g} / \mathrm{kg}-0.57 \pm 0.18 \mu \mathrm{g} / \mathrm{kg})$, though the decrease was exhibited less than in the cortical mucus of the cervix $(0.67 \pm 0.06 \mu \mathrm{g} / \mathrm{kg})$. At the first stage of foaling Pb levels in mares' blood were twice as high as $\mathrm{Cd}$; in $\mathrm{UCf} \mathrm{Pb}$ was not identified, Cd didn't deposit but penetrated into the fetal liver where its levels were 11 times higher than that of $\mathrm{Pb}$. Presence of $\mathrm{Cd}$ in allantoic fluid indicated its ability to excrete through the kidneys. Pb concentration in ALMf were 26 times higher than in the chorion and 3.7 times higher in FPCm than in ALFf. Pb levels in amniotic fluid were 1.3 times lower than in allantoic fluid and almost 4.2 times lower than in the fetal liver. Pb levels in AMF and ALF exceeded its concentration in the umbilical cord by 24.5 and 31 times respectively. 


\title{
Проникність плацентарного бар'єру для Кадмію (Cd) та Плюмбуму (Pb) протягом тільності корів та під час жеребіння кобил
}

\author{
Г.М. Калиновський ${ }^{1}$, Л.Г. Свтух ${ }^{1}$, В.Л. Шнайдер ${ }^{1}$, В.В. Захарін ${ }^{1}$, В.В. Карпюк ${ }^{1}$, М. Омеляненко ${ }^{2}$ \\ ${ }^{1}$ Житомирський наиіональний агроекологічний університет, м. Житомир, Украӥна \\ ${ }^{2}$ Національний університет біоресурсів і природокористування України, м. Київ, Украӥна
}

\begin{abstract}
Досліджено проникність плацентарного бар'єру корів для Кадмію (Cd) та Плюмбуму (РЬ) в динаміці тільності в напрямку кров матері $(K M) \rightarrow$ материнська частина плаценти (МЧП) $\rightarrow$ фетальна частина плаценти (ФЧП) $\rightarrow$ пуповинний канатик (ПК) $\rightarrow$ печінка плода (ПП) $\rightarrow$ амніотична (АМР) і алантоїсна (АЛР) рідини та під час отелення в умовно чистій $i$ забрудненій радіонуклідами зонах (РАЗ), в коркові слизу шийки матки за введення коровам у сухостійний період тканинного препарату фетоплачентат, згодовування в складі раціону суміші сапоніту і сірки; кобил за перебігу жеребіння: кров матері (КК) $\rightarrow$ фетальна частина плаценти кобили (ФЧПК) $\rightarrow$ пуповинний канатик лошати (ПКЛ) $\rightarrow$ печінка лошат (ПЛ) $\rightarrow$ амніотична (АМРЛ) $і$ алантоїсна (АЛРЛ) рідини $\rightarrow$ алантоїсна оболонка лошати (АЛОБЛ). Вік плодів протягом тільності визначали за анатомічними параметрами, вміст Pb i Cd у крові та в субстратах - иляхом атомно-абсорбиійної спектрофотометрії (ДОСТ 3017896). За окремого оиінювання МЧП (карункули) і ФЧП (котеледони) їхня бар'єрна функція максимально проявлялася щзодо Pb $i$ Cd на 4-5 місяиях тільності і збігалася з найвищою конщентраиією в печінці плода, вартоні нові драглі абсорбували Cd на 3-4, Pb на 4-5 місяиях, з наближенням отелення їх рівень в АМР зменшувався, в АЛР зростав. Під впливом фетоплацентату в МЧП $і$ ФЧП С акумулювався більше в АЛР і АМР, менше - в коркові слизу шийки матки. Свинець накопичувався в МЧП всіх корів в однаковій концентрації $(0,46 \pm 0,18 м 2 / к 2$ - зона РАЗ і 0,47 $\pm 0,17$ мг/кг - умовно чиста), в умовно чистій менше в АЛР у 8 разів $(0,62 \pm 0,16$ мг/кг $i$ 0,08 \pm

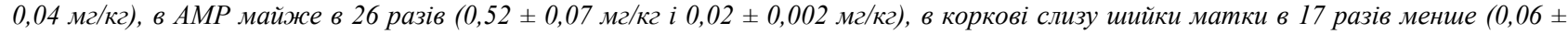

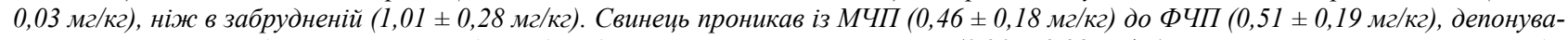
вся у внутрішнє середовище матки звідки абсорбувався муцинами корка слизу (1,01 0,28 мг/кг) шийки матки. Із організму плода Pb виділявся в АMP $(0,52 \pm 0,07$ мг/кг) $і$ в АЛР (0,62 $\pm 0,16$ мг/кг). За згодовуванням мінеральної добавки бар'єрна функція МЧП $(0,23 \pm 0,14 \mathrm{мг/ \kappa г)} \mathrm{знижувалася} \mathrm{і} \mathrm{Рь} \mathrm{накопичувавася} \mathrm{в} \mathrm{ФЧП}(0,47 \pm 0,11 \mathrm{мг/ \kappa г)} \mathrm{в} 2$ рази більше, а в алантоїсній $(0,16 \pm 0,05 \mathrm{мг/ \kappa г)} i$ в амніотичній (0,38 $\pm 0,10$ мг/кг) рідинах менше, ніж в корів контрольної групи $(0,62 \pm 0,16$ мг/кг; $P<0,05$ i 0,52 $\pm 0,07$ мг/к2; $P<0,05$ відповідно), а в коркові слизу шийки матки він депонувався $(2,47 \pm 0,26$ мг/кг; $P<0,001)$. За ін' єкцій фетоплацентату знижувалася бар'єрна здатність МЧП (0,06 0,01 мг/кг) порівняно з контролем (0,46 $\pm 0,17$ мг/кг - 0,57 $\pm 0,18$ мг/кг), але менше, ніж в коркА слизу шийки матка $(0,67 \pm 0,06$ мг/кг). В крові кобил у першу стадію жеребіння рівень Рb в 2 рази вищий, ніж Сd - 8 ПКЛ реєстрували сліди $\mathrm{Pb}, \mathrm{Cd}$ не депонувався, поступав у печінку плода, де його конщентрація в 11 разів була вища, ніж Рb. Кониентрачія $C d$ в АЛРЛ рідині свідчить про його виділення через нирки. Вміст Рь вищий в АЛОБЛ в 26 разів, ніж в хоріальній, 6 ФЧПК - у 3,7 разу, ніж в АЛРЛ рідині. В АМРЛ, РЬ накопичувався в 1,3 рази менше, ніж в АЛРЛ, і майже в 4,2 разу, ніж у печінці плода. В АМРЛ депонувалося $\mathrm{Pb}$ в 24,5, а в АЛРЛ - в 31 раз більше, ніж у пуповинному канатику.
\end{abstract}

Ключові слова: кров, пуповинний канатик, плід, печінка, навколоплідні рідини.

\section{Вступ}

Мінеральні речовини, що входять до складу тканин і клітин організму тварин, поступають 3 кормом і водою. Їх уміст у кормах залежить від рівня в грунті, підготовки корму до згодовування, стану організму. Одночасно організм тварин захищений від впливу факторів зовнішнього середовища системою бар'єрів, функція яких скерована на збереження відносної постійності його внутрішнього середовища (Arshavskij, 1977).

Оцінити прямий вплив таких поллютантів, як важкі метали, радіоактивні елементи, органічні сполуки та інших можна лише за умови поступання їх 3 кормом і накопичення в організмі. Одночасно треба враховувати наявність в організмі гістогематичних бар'єрів, завдяки яким реалізується ефективний селективний транспорт і забезпечується захист потомства від впливу різних хімічних та інших факторів.

Дослідження транслокації хімічних елементів у тварин і хронічного впливу на них токсикантів в ланцюгу "раціон - материнський організм - плацента плід” обмежені (Muhacheva \& Bezel', 2015).

$€$ повідомлення про міграцію важких металів в системі "грунт - корм - вода - тільна корова - молози- во” (Krajneva, 2009), “мати - плацента - плід” у рудої польовки (Muhacheva \& Bezel', 2015).

Більшість досліджень виконані в гуманній медицині і вони стосуються наявності важких металів у крові матері, в репродуктивних органах і в ембріонах (Thompson \& Bannigan, 2008; Biasek et al., 2014; Bonglaisin, et al., 2017), в плодах i плаценті (Zahrzewska et al., 2002; Kippler et al., 2010; Olszowski et al., 2016), особливостей стану плацентарного бар'єра жінок під впливом екзогенних і ендогенних факторів (Griffiths \& Campbell, 2015).

Одним з найрозповсюдженіших і токсичних важких металів в Україні, що впливає на формування дітей у пренатальний період їх розвитку, $є$ кадмій. Він накопичується в плаценті, проникає до плода і може бути причиною ембріотоксичних і тератогенних ефектів (Hanson et al., 2012; Röllin et al., 2015; Ostrovskaja, 2016; Muoth et al., 2016).

Наявність $\mathrm{Cd}$ в плаценті викликає внутрішньоутробне затримання росту плода (Ostrovskaja, 2016), негативно впливає на його антропометричні показники (Lianos \& Ronco, 2009; Ventskivskyi, 2010; Lin et al., 2011; Ni et al., 2014).

Для токсичних елементів, зокрема $\mathrm{Cd}$, плацента виконує роль часткового бар'єру, через який $\mathrm{Pb}$ про- 
никає вільно. Плацентарний бар'єр рудої польовки обмежує надлишкове поступання до плода $\mathrm{Cu}, \mathrm{Zn}, \mathrm{Cd}$, але проникливий для $\mathrm{Pb}$. У плаценті тварин із забрудненої токсинами території протягом вагітності накопичувалось $\mathrm{Cd}$ в середньому в 5 разів більше, а за $\mathrm{Pb}$ вірогідної різниці не виявлено (Sun et al., 2014; Muhacheva \& Bezel', 2015).

Концентрація Сd в плаценті жінок коливається в межах від 1,2 до 53,0 нт. Його рівень у ній вищий, ніж у крові матері і в 100 разів більший, ніж у пуповинній крові (Kippler et al., 2010; Estaban-Vasallo et al., 2012).

Визначений в еритроцитах матері і в пуповинній крові $\mathrm{Cd}$ в 100\% випадків проникає в кров плода i його виявляють у ній в дітей після народження (Chen et al., 2014).

Накопичення $\mathrm{Cd}$ в плаценті жінок відображене в працях багатьох авторів (Lianos \& Ronko, 2009; Lin et al., 2011; Kippler et al., 2012; Estaban-Vasallo et al., 2012; Hanson et al., 2012; Ni et al., 2013; Biasek et al., 2014; Chen et al., 2014; Sun et al., 2014; Berglund et al., 2015; Al-Salen, 2015; Vilanyr et al., 2015; Sanders et al., 2015; Olszowski et al., 2016; Xu et al., 2016; Wang et al., 2016).

Серед функціональних особливостей захисних сил систем організму, що запобігають надходженню до плода шкідливих і метаболічноактивних токсикантів, плаценті належить основна роль (Biletska \& Onul, 2014; Vilahur et al., 2014).

Проникання лікарських засобів від матері до плода залежить від структури плаценти, $\mathrm{Cd}$ в популяціях тварин - від його дородової експозиції (Röllin et al., 2015), у людей - від статевих і вікових відмінностей (Walker et al., 2017). Оцінка проникності Cd взаємозв'язана 3 статусом гемоглобіну (Bonglaisin et al., 2017) і наявності наночасток, які впливають на проникність плацентарного бар'єра (Muoth et al., 2015), що узгоджується 3 отриманими результатами при моделюванні запальних реакцій у відповідь на бактеріальну інфекцію (Sanders et al., 2015; Qin et al., 2018).

Біологічна індикація екологічно захищених порушень у системі “мати - плацента - плід” є однією 3 найважливіших проблем у збереженні людей і тварин як біологічного виду. На організм вагітних впливає значний комплекс антропогенних та інших факторів, що призводять до порушення функції плаценти і негативно відбиваються на внутрішньоутробному розвитку плода. Екзогенні фактори будь-якого походження реалізують свої властивості на рівні клітинних мембран, що проявляється зміною бар'єрної функції плаценти Деструктивні зміни в плаценті зумовлюють розвиток плацентарної недостатності, що корелює 3 неблагополучним перебігом вагітності, загрозами переривання вагітності, гестозами (Fedorova et al.,1994; Zubzhickaja et al., 2015; Al-Salec, 2015; Amaya et al., 2015).

Пренатальний вплив Cd має негативні наслідки не лише на розвиток плода, а й причиною захворювань дорослого організму. Установлено прямий зв'язок між умістом $\mathrm{Cd}$ і $\mathrm{Pb}$ та високим рівнем металотіонеїну в плаценті, оскільки він забезпечує захисний механізм протидії важких металів (Tekin et al., 2012). Надходження $\mathrm{Cd}$ від матері до плода $є$ основним джерелом його негативного впливу на дітей (Chen et al., 2014).

Кадмій і свинець, проникаючи через плаценту із крові матері, накопичуються в тканинах плода, можуть викликати ембріотоксичні і тератогенні ефекти. Токсикокінетика важких металів в організмі загалом, у вагітних жінок зокрема, залежить від багатьох факторів і розкриття механізмів їх міграції $є$ надзвичайно важким завданням. Дослідженнями співвідношення вмісту важких металів у материнській крові, плаценті та пуповинній крові новонароджених установлено, що найшвидше із крові матері до плода проникають свинець і нікель (Ventskivskyi, 2010; Esteban-Vasallo et al., 2012; Chen et al., 2014; Ni et al., 2014; Muoth et al., 2016).

Дослідження проникності плацентарного барєру в сільськогосподарських тварин для $\mathrm{Cd} \mathrm{i} \mathrm{Pb}$ за різного стану організму та впливу екологічних факторів, в тому числі й антропогенного, доповнюють можливості оцінювання і порівняння морфологічної структури і фізіологічної здатності плаценти ссавців як загально біологічного процесу.

\section{Матеріал і методи досліджень}

Проведено дві серії досліджень. Матеріалом для виконання першої серії дослідження були різного терміну тільності клінічно здорові корови, яких забивали в умовах м'ясокомбінату, що належали господарствам, які функціонують в умовах Північносхідної біогеохімічної провінції Житомирської області України. Від корів відразу після забою відбирали матки, з яких вичленяли плаценту, пуповину, аллантоїсну і амніотичну рідини, а з плодів - печінку, під час отелення - проби венозної крові, аллантоїсну і амніотичну рідини, пуповиний канатик телят (вартанові драглі), фетальну частину плаценти. Термін тільності визначали за анатомічними параметрами: довжина, вага, наявність волосяного покривива, кількість зубів. Материнську частину плаценти (карункули) екстерпували протягом 30 хвилин після народження теляти.

Метою другої серії досліджень було вивчення впливу згодовування сухостійним коровам господарств, що функціонують в умовно чистій щодо радіаційного забруднення (РАЗ) території та належать до 3-ї зони РАЗ, мінеральної добавки в складі суміші сапоніту та сірки і введення тканинного препарату фетоплацентату на проникність $\mathrm{Cd}$ i $\mathrm{Pb}$ через плацентарний бар'єр корів.

Якщо у жуйних тварин (корова, коза, вівця) із множинним типом плаценти можна легко відокремити від стінки матки МЧП (карункул), а від судинної оболонки ФЧП (котиледон), то у всіх інших свійських тварин цього зробити неможливо.

У самиць 3 розсіяним типом плаценти (pl. dessiminata), до яких належить кобила, не вдається анатомічно відпрепаровувати i вичленити окремо МЧП і ФЧП, як це можна зробити в жуйних. Вважаємо за можливе для оцінки стану проникності плацен- 
тарного бар'єру у самиць з розсіяним типом плаценти та епітеліохоріальним зв'язком між його материнською і фетальною частинами, об'єктивними будуть результати дослідження, якщо за ФЧП брати хоріон, а за МЧП - ендометрій, в крипти якого занурюються ворсинки хоріона.

Зважаючи на це, при дослідженні проникності ПБК під час жеребіння за ФЧП взято хоріон, а МЧП не була врахована, бо отримання ендометрію як материнської частини плаценти загрожує кровотечею. Таким чином, нами досліджено проникність ПБК за потоком крові в напрямку КК $\rightarrow$ фетальна частина плаценти кобил $\rightarrow$ (ФЧПК) $\rightarrow$ пуповинний канатик лошати (ПКЛ) $\rightarrow$ печінка лошат (ПЛ) $\rightarrow$ амніотична (АМРЛ) та алантоїсна (АЛРЛ) рідини $\rightarrow$ алантоїсна оболонка лошат (АЛОБЛ).

Нами досліджено лише селективне проникнення $\mathrm{Cd}$ та $\mathrm{Pb}$ в напрямку мати $\rightarrow$ плід, яке регулюється плацентарним бар'єром, що функціонує як клапан. У напрямку плід $\rightarrow$ мати всі речовини, що утворилися в результаті обміну в його організмі, переходять до матері, не затримуючись плацентарним бар'єром, оскільки він функціонує подібно до вентеля (Arshavskij, 1977; Rosin, 1977).

Матеріал для визначення проникності ПБК відбирали від кобил орловської та російської рисистих прорід на кінному заводі Луганської області України: кров - у підготовчу стадію жеребіння, навколоплодові рідини, амніотичну та алантоїсну - під час другої стадії жеребіння, пуповинний канатик і оболонки плодів - після їх відділення і вигнання із родового шляху, а якщо лоша нороджувалось у “сорочці”, то після їх розтину. Печінку отримували від трьох лошат, народжених у “сорочці”, яким не було надано своєчасної допомоги і вони загинули від асфіксії.

Дослідження відібраних субстратів з визначенням y них $\mathrm{Cd}$ i $\mathrm{Pb}$ проводили методом атомноабсорбційної спектрофотометрії (ГОСТ 30170896) в Житомирській обласній лабораторії ветеринарної медицини.

\section{Результати та їх обговорення}

Протягом тільності, як нами встановлено, рівень $\mathrm{Cd}$ i Pb в досліджуваних субстратах змінюється (табл. $1,2)$.

Проникність Сd через ПБ привертає увагу тим, що протягом двох періодів (табл. 1) тільності він накопичується в карункули, як МЧП, і його концентрація збільшується $346,000 \pm 0,007$ мкг/кг на 2-3 місцях тільності до $165,000 \pm 0,029$ мкг/кг на 4-5 місцях ( $\mathrm{P}<0,01)$, а на 6-7 місцях тільності вона знижується до $52,000 \pm 0,011$ мкг/кг $(\mathrm{P}<0,01)$.

В котиледони, як ФЧП, концентрація $\mathrm{Cd}$ утримується на стабільному рівні протягом всього періоду тільності.

Таким чином, МЧП максимально акумулює $\mathrm{Cd}$ на 4-5 місцях тільності, ФЧП - протягом усього періоду тільності стабільно до певного рівня (табл. 1).

Зі збільшенням термінів тільності, на 4-5 місяці, рівень $\mathrm{Cd}$ в печінці плода збільшувався у 8 разів $(56,000 \pm 0,011$ мкг/кг - 428,000 $\pm 0,037$ мкг/кг), а на 6-7 місцях знижуєвався в 4 рази $(112,00 \pm$ 0,016 мкг/кг), але він вищий у 2 рази, ніж на 2-3 місцях тільності.

Концентрація Cd у вартонових драглях на 4-5 місцях тільності $(21,000 \pm 0,008$ мкг/кг) менша, ніж на 23 -му $(61,000 \pm 0,003$ мкг/кг), а на 6-7-му місяцях вона зросла $(36,000 \pm 0,004$ мкг/кг), але нижча порівняно 3 2-3 місяцями (Р < 0,001). Накопичившись в вартонових драглях, Cd в меншій кількості надходить в організм плоду. Так проявляється іiі бар'єрна функція.

Динаміка концентрації Cd в амніотичній рідині підтверджує захисну функцію вартонових драглів щодо плода, оскільки в ній іiі рівень 3 4-5 місяця до кінця тільності нижча.

Аналогічна динаміка $\mathrm{Cd}$ в аллантоісній рідині, де 3 4-5 місяця тільності його концентрація вища, ніж в амніотичній рідині.

Таблиця 1

Вміст Сd в досліджуваних субстратах, $\mathrm{M} \pm \mathrm{m}, \mathrm{Mг} / \kappa г, \mathrm{n}=5$

\begin{tabular}{|c|c|c|c|c|c|c|}
\hline \multirow[b]{2}{*}{$\begin{array}{c}\text { Період } \\
\text { тільності, } \\
\text { місяць }\end{array}$} & \multicolumn{6}{|c|}{ Досліджувані субстрати, мкг/кг } \\
\hline & $\begin{array}{c}\text { Карункул } \\
\text { (МЧП) }\end{array}$ & $\begin{array}{c}\text { Котиледон } \\
\text { (ФЧП) }\end{array}$ & $\begin{array}{c}\text { Вартонові } \\
\text { драглі } \\
\text { (пупковий } \\
\text { канатик) }\end{array}$ & $\begin{array}{c}\text { Амніотична } \\
\text { рідина } \\
\text { (АМР) }\end{array}$ & $\begin{array}{c}\text { Алантоїсна } \\
\text { рідина } \\
\text { (АЛР) }\end{array}$ & Печінка плода \\
\hline $\begin{array}{c}\text { Перший, } \\
2-3\end{array}$ & $\begin{array}{c}46,000 \pm \\
0,017\end{array}$ & $\begin{array}{c}47,000 \pm \\
0,015\end{array}$ & $\begin{array}{c}61,00 \pm \\
0,03\end{array}$ & $\begin{array}{c}25,000 \pm \\
0,003\end{array}$ & $\begin{array}{c}18,000 \pm \\
0,007\end{array}$ & $\begin{array}{c}56,000 \pm \\
0,013\end{array}$ \\
\hline $\begin{array}{c}\text { Другий, } \\
\text { 4-5 }\end{array}$ & $\begin{array}{c}165,000 \pm \\
0,029 * *\end{array}$ & $\begin{array}{c}47,000 \pm \\
0,011\end{array}$ & $\begin{array}{l}21,000 \pm \\
0,008 * *\end{array}$ & $\begin{array}{c}10,000 \pm \\
0,003 *\end{array}$ & $\begin{array}{c}15,000 \pm \\
0,006\end{array}$ & $\begin{array}{l}428,000 \pm \\
0,037 * * *\end{array}$ \\
\hline $\begin{array}{c}\text { Третій, } \\
\text { 6-7 }\end{array}$ & $\begin{array}{c}52,000 \pm \\
0,011 * * /\end{array}$ & $\begin{array}{c}44,000 \pm \\
0,007\end{array}$ & $\begin{array}{c}36,000 \pm \\
0,004 / * * *\end{array}$ & $\begin{array}{l}10,000 \pm \\
0,003 / * *\end{array}$ & $\begin{array}{c}15,000 \pm \\
0,006\end{array}$ & $\begin{array}{c}112,000 \pm \\
0,016^{* * * / *}\end{array}$ \\
\hline $\begin{array}{c}\text { Отелення } \\
\text { Кров: } \\
22,000 \pm 0,045\end{array}$ & $\begin{array}{c}160,000 \pm \\
0,022\end{array}$ & $\begin{array}{c}126,000 \pm \\
0,007\end{array}$ & $\begin{array}{c}60,000 \pm \\
0,006\end{array}$ & $\begin{array}{c}80,000 \pm \\
0,005\end{array}$ & $\begin{array}{c}78,000 \pm \\
0,020\end{array}$ & $\begin{array}{c}40,000 \pm \\
0,002\end{array}$ \\
\hline
\end{tabular}

Примітки: * - до межі дробу - достовірність між попереднім терміном досліджень, після риски дробу - достовірність між початковим і кінцевим терміном 
Проникність ПБ для $\mathrm{Pb}$ відрізняється від $\mathrm{Cd}$ не тільки тим, що його концентрація вища, а й динамікою у всіх субстратах, аналогічній лише для МЧП (табл. 1, 2): в ФЧП його рівень на 4-5 місцях тільності щодо 2-3 місяців зростав більш ніж 2 рази, а на 6-7 місцях знижувався, але він вищий порівняно 3 першим періодом тільності.

Таким чином, динаміка проникності обох частин ПБ для $\mathrm{Pb}$ аналогічна, але бар'єрна функція МЧП вища, ніж ФЧП.

Динаміка накопичення $\mathrm{Pb}$ в обох частинах ПБ в вартонових драглях, печінці плода і в амніотичній рідині протягом тільності аналогічна. На 4-5 місяцях тільності в них накопичується максимальна кількість $\mathrm{Pb}$.

По шляху кров матері $\rightarrow$ печінка плода концентрація Рb поступово знижувалась в напрямку: МЧП $\rightarrow$ ФЧП $\rightarrow$ вартонові драглі. Таким чином, поряд з МЧП і ФЧП бар'єрну функцію на шляху мати $\rightarrow$ плід виконують вартонові драглі пуповини. У печінці плода $\mathrm{Pb}$ акумулювався в концентрації вищій, ніж в провізорних органах.

\section{Таблиця 2}

Вміст $\mathrm{Pb}$ в досліджуваних субстратах, $\mathrm{M} \pm \mathrm{m}, \mathrm{мг} / \kappa г, \mathrm{n}=5$

\begin{tabular}{|c|c|c|c|c|c|c|}
\hline \multirow[b]{2}{*}{$\begin{array}{l}\text { Період } \\
\text { тільності } \\
\text { місяць }\end{array}$} & \multicolumn{6}{|c|}{ Досліджувані субстрати, мкг/кг } \\
\hline & $\begin{array}{l}\text { Карункул } \\
\text { (МЧП) }\end{array}$ & $\begin{array}{l}\text { Котиледон } \\
\text { (ФЧП) }\end{array}$ & $\begin{array}{l}\text { Вартонові } \\
\text { драглі } \\
\text { (пупковий } \\
\text { канатик) }\end{array}$ & $\begin{array}{c}\text { Амніотична } \\
\text { рідина } \\
\text { (АМР) }\end{array}$ & $\begin{array}{c}\text { Алантоїсна } \\
\text { рідина } \\
\text { (АЛР) }\end{array}$ & $\begin{array}{c}\text { Печінка } \\
\text { плода }\end{array}$ \\
\hline $\begin{array}{c}\text { Перший, } \\
2-3\end{array}$ & $\begin{array}{c}433,00 \pm \\
0,04\end{array}$ & $\begin{array}{c}218,000 \pm \\
0,027\end{array}$ & $\begin{array}{c}240,000 \pm \\
0,027\end{array}$ & $\begin{array}{c}110,000 \pm \\
0,015\end{array}$ & $\begin{array}{c}335,000 \pm \\
0,044\end{array}$ & $\begin{array}{c}606,000 \pm \\
0,076\end{array}$ \\
\hline $\begin{array}{c}\text { Другий, } \\
\text { 4-5 }\end{array}$ & $\begin{array}{c}1071,000 \pm \\
0,121 * * *\end{array}$ & $\begin{array}{l}485,000 \pm \\
0,024 * * *\end{array}$ & $\begin{array}{l}431,00 \pm \\
0,05 * *\end{array}$ & $\begin{array}{c}159,000 \pm \\
0,015 *\end{array}$ & $\begin{array}{c}178,000 \pm \\
0,019 * *\end{array}$ & $\begin{array}{c}1141,000 \pm \\
0,163 * *\end{array}$ \\
\hline $\begin{array}{c}\text { Третій, } \\
6-7\end{array}$ & $\begin{array}{r}676,000 \pm \\
0,096^{* * / * *}\end{array}$ & $\begin{array}{c}280,000 \pm \\
0,023 * * *\end{array}$ & $\begin{array}{c}130,000 \pm \\
0,015^{* * * / * *}\end{array}$ & $\begin{array}{c}38,000 \pm \\
0,009 * * * * * *\end{array}$ & $\begin{array}{c}138,000 \pm \\
0,046 / * *\end{array}$ & $\begin{array}{c}136,000 \pm \\
0,042 * * * / * * *\end{array}$ \\
\hline $\begin{array}{c}\text { Отелення } \\
\text { Кров: } 22,000 \pm \\
0,045\end{array}$ & $\begin{array}{l}45,000 \pm \\
0,004\end{array}$ & $\begin{array}{c}126,000 \pm \\
0,007\end{array}$ & $\begin{array}{c}64,000 \pm \\
0,150\end{array}$ & $\begin{array}{c}60,000 \pm \\
0,003\end{array}$ & $\begin{array}{c}20,000 \pm \\
0,002\end{array}$ & $\begin{array}{c}80,000 \pm \\
0,004\end{array}$ \\
\hline
\end{tabular}

Примітки: *-до межі дробу - достовірність між попереднім терміном досліджень, після рикси дробу - достовірність між початковим і кінцевим терміном

Накопичившись в печінці, $\mathrm{Pb}$ мігрує в організмі плода. Його концентрація підвищується в амніотичній і аллантоїсній рідинах на 2-3 місяцях тільності, а 3 45 місяця знижується.

Вища концентрація $\mathrm{Pb}$ в аллантоїсній рідини свідчить про шляхи його виділення із організму плода.

Динаміка накопичення $\mathrm{Pb}$ в обох частинах ПБ, в вартонових драглях і печінці плода протягом тільності аналогічна.

В амніотичній рідині протягом всієї тільності вміст $\mathrm{Pb}$, порівняно 3 іншими субстратами, найнижчий. Збільшення його рівня на 4-5 місяцях тільності в амніотичній рідині можна пояснити тим, що найвища в цей період його проникність через ПБ обумовлює високу концентрацію у всіх досліджуваних субстратах.

Розглядаючи вміст $\mathrm{Cd}$ i $\mathrm{Pb}$ в амніотичній рідині через призму інтенсивності проникності ПБ, необхідно враховувати джерела іiі утворення, функцію і значення для плода під час його внутрішньоутробного розвитку. Найважливіше в розгляді цього питання те, що амніотична рідина - середовище проживання плода, метаболізму речовин і накопичення продуктів катаболізму (Arshavskij, 1977; Ventskivskyi, 2010).

Найменша концентрація $\mathrm{Pb}$ в амніотичній рідині свідчить про високий захист від нього середовища проживання плода, в печінці плода - про іï бар'єрну функцію і міграцію його в організмі.
Під час отелення, при наявності $\mathrm{Cd}$ в крові матері $(22,000 \pm 0,045$ мкг/кг) в МЧП його концентрація в 7,3 разу вища $(160,000 \pm 0,002$ мкг/кг) або така ж, як і в кінці першої половини тільності $(165,000 \pm$ 0,029 мкг/кг), в ФЧП - майже в 5,1 разу вища.

Отже, можемо припустити, що під кінець тільності максимально проявляється бар'єрна функція обох частин плацентарного бар'єра щодо проникнення шкідливих речовин із крові матері до плода. У печінці плода $\mathrm{Cd}$ порівняно зі всіма термінами тільності найменше, бо він у найбільшій концентрації накопичувався в провізорних органах, які під час отелення виділяються $з$ організму корів.

Результати наших досліджень підтверджують наведені дані про абсорбцію муцинами слизового корка шийки матки тільних корів речовин, що утворюються в порожнині матки. Як видно 3 даних (табл. 3), уміст мікроелементів у коркові слизу шийки матки перед народженням телят коливався в незначних межах. За результатами наших досліджень, він залежить не тільки від вмісту мікроелементів у кормах, а й від того, що згодовували і вводили тваринам протягом сухостійного періоду.

Нами встановлено, що у корів контрольної групи в МЧП в умовно чистій зоні найвища концентрація $\mathrm{Cd}$ $(0,16 \pm 0,02 \mathrm{мг/кГ),} \mathrm{а} \mathrm{в} \mathrm{ФЧП} \mathrm{в} 2,7$ разу менша $(0,06 \pm$ 0,006 мг/кг). Це означає, що в кінці фізіологічного перебігу тільності, тобто під час отелення, вміст кад- 
мію в плодовій частині плаценти нижчий в 2,7 разу (на 62\%), ніж в материнській.

В амніотичній рідині містилося $0,07 \pm 0,002$ мг/кг кадмію, що у 1,2 разу (14\%) більше, ніж в фетальній частині плаценти $(0,06 \pm 0,006$ мг/кг). Отже, із фетальної частини плаценти кадмій проникає до організма плода і накопичується в амніотичній рідині. Порівняно 3 амніотичною $(0,07 \pm 0,002$ мг/кг) в алантоїсній рідині $(0,04 \pm 0,002$ мг/кг) концентрація кадмію майже в 1,8 разу нижча. Таким чином, під час отелення на шляху проникнення кадмію із крові матері до плода основним бар'єром є материнська частина плаценти. У ній більше затримується кадмію, ніж у фетальній частині плаценти (табл. 3).

У корів першої дослідної групи, яким згодовували протягом сухостійного періоду тільки суміш мінеральної добавки, накопичення кадмію в МЧП порівняно 3 контролем знизилось $(0,11 \pm 0,02-0,16 \pm 0,02$ мг/кг, $\mathrm{P} \geq 0,05)$ у 1,5 разу (31\%). Якби його вміст не змен- шився у ФЧП $(0,02 \pm 0,003$ і $0,06 \pm 0,006$ мг/кг, $\mathrm{P} \leq$ $0,001)$ у 3 рази $(67 \%)$ та в амніотичній $(0,06 \pm 0,003 \mathrm{i}$ $0,07 \pm 0,002 \mathrm{мг/кг,} \mathrm{P} \leq 0,01)$ рідині у 1,2 рази $(14 \%)$ i в коркові слизу $(0,06 \pm 0,003$ і $0,08 \pm 0,005$ мг/кг, $\mathrm{P} \leq$ $0,01)$ у 1,3 разу $(25 \%)$, то можна було б твердити про його затримання і накопичення в материнській частині плаценти.

Оскільки порівняно з контролем концентрація кадмію знизилась у МЧП і ФЧП, в амніотичній рідині, в коркові слизу шийки матки тварин першої дослідної групи, то $\epsilon$ всі підстави стверджувати, що елемент став менше проникати через бар'єр материнської частини плаценти. Очевидо, що зменшення проникнення кадмію із крові до плаценти сталося завдяки властивості сапоніту адсорбувати мікроелементи в організмі матері з подальшим виведенням їх в складі калових мас і сечі.

\section{Таблиця 3}

Вміст Cd у досліджуваних субстратах корів під час отелення в умовно чистій щодо РАЗ території, $\mathrm{M} \pm \mathrm{m}, \mathrm{мг} / \mathrm{к}, \mathrm{n}=5$

\begin{tabular}{lccc}
\hline \multirow{2}{*}{ Досліджувані субстрати } & \multicolumn{3}{c}{ Групи корів } \\
\cline { 2 - 4 } & \multicolumn{1}{c}{ Контрольна } & 1 дослідна & $0,08 \pm 0,01-/ * *$ \\
Карункул (МЧП) & $0,16 \pm 0,02$ & $0,11 \pm 0,02$ & $0,02 \pm 0,004-/ * * *$ \\
Котиледон (ФЧП) & $0,06 \pm 0,006$ & $0,02 \pm 0,003 * * *$ & $0,06 \pm 0,003 * *$ \\
Амніотична рідина (АМР) & $0,07 \pm 0,002$ & $0,04 \pm 0,01$ & $0,03 \pm 0,003-/ * *$ \\
Алантоїсна рідина (АЛР) & $0,04 \pm 0,002$ & $0,06 \pm 0,003 * *$ & $0,04 \pm 0,008-/ * *$ \\
Слиз шийки матки & $0,08 \pm 0,005$ &
\end{tabular}

Додаткове введення коровам другої дослідної групи тканинного препарату теж сприяло зниженню концентрації кадмію порівняно із коровами контрольної групи: в МЧП - у 2 рази $(0,08 \pm 0,01$ і $0,16 \pm$ $0,02 \mathrm{мг/кг,} \mathrm{P} \leq 0,01)$, у ФЧП - в 3 рази $(0,02 \pm 0,004$ i $0,06 \pm 0,006 \mathrm{мг/ \kappa г,} \mathrm{P} \leq 0,001)$, в амніотичій $(0,05 \pm$ $0,002$ і $0,07 \pm 0,002$ мг/кг, $\mathrm{P} \geq 0,05)$ і в алантоїсній $(0,03 \pm 0,003$ і $0,04 \pm 0,002$ мг/кг, $\mathrm{P} \leq 0,01)$ рідинах відповідно у 1,4 і 1,3 разу та коркові слизу шийки матки в 2 рази $(0,04 \pm 0,008$ і $0,08 \pm 0,005$ мг/кг, $\mathrm{P} \leq 0,01)$.

Порівняно 3 першою дослідною групою корів, яким згодовували тільки суміш мінеральної добавки, введення тканинного препарату проявилось зменшенням накопичення $\mathrm{Cd}$ в МЧП $(0,08 \pm 0,01$ i $0,11 \pm 0,02 \mathrm{мг} / \kappa г, \mathrm{P} \geq 0,05)$ в 1,4 рази, в $\mathrm{AMP}(0,05 \pm$ $0,002$ i $0,06 \pm 0,003$ мг/кг, $\mathrm{P} \leq 0,05)$ i АЛР $(0,03 \pm 0,003$ i $0,04 \pm 0,01 \mathrm{мг/ \kappa г,} \mathrm{P} \geq 0,05)$ рідинах у 1,2 і 1,3 рази відповідно та коркові слизу $(0,04 \pm 0,008$ i $0,06 \pm 0,003$ мг/кг) у 1,5 разу.

Отже, згодовування коровам протягом запуску мінеральної добавки у складі суміші сапоніту і сірки і додаткове ін'єктування тканинного препарату сприяло зниженню в коркові слизу шийки матки кадмію порівняно з коровами контрольної групи $(\mathrm{P} \leq 0,01)$.

За вмістом свинцю в коркові слизу результати досліджень характеризуються певними особливостями. У корів першої дослідної групи, яким згодовували тільки сапоніт і сірку, концентрація свинцю (0,03 \pm 0,007 мг/кг) (табл. 4) так само, як і кадмію, нижча, ніж у контрольних тварин $(0,06 \pm 0,03$ мг/кг, $\mathrm{P} \geq 0,5)$ у 2 рази.

У корів другої дослідної групи при додатковому введенні тканинного препарату концентрація свинцю в коркові слизу становила $(0,17 \pm 0,04$ мг/кг і була майже в 5,7 разу вища, ніж у корів першої дослідної групи $(0,03 \pm 0,007$ мг/кг; $\mathrm{P} \geq 0,05)$ і в 3 рази вища порівняно 3 коровами контрольної групи $(0,06 \pm$ $0,03$ мг/кг, $\mathrm{P} \leq 0,05)$.

У корів контрольної групи вміст свинцю в МЧП менший $(0,47 \pm 0,17$ мГ/кГ), ніж у ФЧП $(0,64 \pm$ 0,15 мг/кг) у 1,4 разу. Це свідчить про те, що материнська частина плаценти до певного граничного рівня гальмує проникнення свинцю до фетальної частини плаценти, на цьому рівні свинець, накопичившись у материнській частині плаценти, долає іiі бар'єрну здатність. За такого стану бар'єрна здатність фетальної частини плаценти підвищується і свинець накопичується в ній теж до певного максимального рівня, а надалі проникає до організму плода. При цьому в амніотичній рідині вміст свинцю менший $(0,02 \pm$ 0,002 мг/кг), ніж в алантоїсній $(0,08 \pm 0,04$ мг/кг) у 4 рази. Вважаємо, що так проявляється захисна здатність самого плода: свинець із його організму виділяється через нирки і накопичується в алантоїсній рідині як первородній сечі. 
Накопичення свинцю в коркові слизу шийки матки корів контрольної групи у більшій концентрації $(0,06 \pm 0,03$ мг/кг), ніж в амніотичній $(0,02 \pm$ 0,002 мг/кг) на $67 \%$, вказує на те, що він проникає через амніотичну оболонку в порожнину матки і абсорбується муцинами корка слизу шийки матки. Це теж один із проявів захисту плода від впливу свинцю.

\section{Таблиця 4}

Вміст свинцю в досліджуваних субстратах корів під час отеленняз умовно чистій щодо РАЗ території, $\mathrm{M} \pm \mathrm{m}$, $\mathrm{Mг} / \mathrm{\kappa г,} \mathrm{n}=5$

\begin{tabular}{lccc}
\hline \multirow{2}{*}{ Досліджувані субстрати } & \multicolumn{3}{c}{ Групи корів } \\
\cline { 2 - 4 } Карункул (МЧП) & Контрольна & 1 дослідна & 2 дослідна \\
Котиледон (ФЧП) & $0,47 \pm 0,17$ & $0,26 \pm 0,01$ & $0,05 \pm 0,01-/ *$ \\
Амніотична рідина (АМР) & $0,64 \pm 0,15$ & $0,42 \pm 0,08$ & $0,27 \pm 0,11$ \\
Алантоїсна рідина (АЛР) & $0,02 \pm 0,002$ & $0,04 \pm 0,02$ & $0,015 \pm 0,002$ \\
Слиз шийки матки & $0,08 \pm 0,04$ & $0,009 \pm 0,0007$ & $0,06 \pm 0,02 * /-$ \\
\hline ำ $*$ * до риски дробу - порівняння результатів із попередньюю групою; * після - із контрольною
\end{tabular}

Примітка: * до риски дробу - порівняння результатів із попередньою групою; * після - із контрольною

Порівняно 3 контрольною групою $(0,47 \pm$ $0,17 \mathrm{мг/ \kappa г,} \mathrm{P} \leq 0,05)$ згодовування коровам першої дослідної групи суміші сапоніту і сірки сприяло меншому накопиченню свинцю в обох частинах плаценти: в карункулі $(0,26 \pm 0,01 \mathrm{мг} / к г$, і $0,42 \pm 0,08$, $\mathrm{P} \leq 0,05)$ у 1,9 рази і котиледоні $(0,64 \pm 0,15$ і $0,42 \pm$ $0,08$ мг/кг, $\mathrm{P} \geq 0,05)$ у 1,5 разу, але так само, як і в контролі, його концентрація вища у котиледоні, ніж в карункулі (табл. 4). Порівняно з контролем, навпаки, збільшився вміст свинцю в амніотичній рідині $(0,02 \pm$ $0,002$ і $0,04 \pm 0,02 \mathrm{мг/кг,} \mathrm{P} \geq 0,05)$ у 2 рази і зменшився в алантоїсній рідині $(0,08 \pm 0,04$ і 0,009 $\pm 0,0007$ мг/кг, $\mathrm{P} \geq 0,05)$ у 9 разів та коркові слизу шийки матки $(0,06 \pm 0,03$ і $0,03 \pm 0,07$ мг/кг, $\mathrm{P} \geq 0,05)$ у 2 рази.

Цю динаміку зміни концентрації свинцю в алантоїсній і амніотичній рідинах і в коркові слизу шийки матки в корів першої дослідної групи можна пояснити, припускаючи таке: при однаковій закономірності зміни концентрації токсиканта в МЧП і в ФЧП під впливом згодовуваної мінеральної добавки він більше накопичується в організмі плода і поступає в амніотичну рідину.

У корів другої дослідної групи, яким додатково ін'єкували тканинний препарат, збереглась така ж тенденція щодо накопичення свинцю в МЧП та ФЧП, але більше виражена: в МЧП $(0,05 \pm 0,01$ мг/кг) зменшилась концентрація свинцю порівняно 3 контрольними тваринами $(0,47 \pm 0,17$ мг/кг $)$ у 9,4 рази $(\mathrm{P} \leq 0,05)$, з першою дослідною групою $(0,26 \pm 0,01$

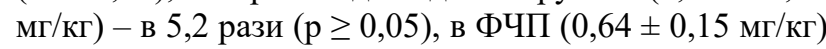
в $2,3(\mathrm{P} \geq 0,05)$ і $1,6(0,42 \pm 0,08$ мг/кг; $\mathrm{P} \geq 0,05)$ рази відповідно.

Вміст свинцю в амніотичній рідині другої дослідної групи $(0,015 \pm 0,002$ мг/кг), порівняно 3 контролем $(0,02 \pm 0,002 \mathrm{мг/ \kappa г)} \mathrm{i} \mathrm{першою} \mathrm{дослідною} \mathrm{групою}$ $(0,04 \pm 0,02 \mathrm{мг/ \kappa г),} \mathrm{в} \mathrm{алантоісній} \mathrm{рідині}(0,08 \pm$ 0,04 мг/кг) порівняно 3 контролем, - знизився у 1,3 $(\mathrm{P} \geq 0,05)$, п першою дослідною $(0,009 \pm 0,0007$ мг/кг) - збільшився у 6,7 разу $(\mathrm{P} \leq 0,05)$.

У корів контрольної групи із зони РАЗ найвища концентрація кадмію виявлена в МЧП $(0,16 \pm$ 0,04 мг/кг, табл. 5), а в ФЧП (0,06 $\pm 0,01$ мГ/кг) вона майже в 2,7 рази нижча. В амніотичній рідині $(0,008 \pm$
0,001 мг/кг) вміст кадмію вищий у 1,1 рази, ніж в алантоїсній $(0,007 \pm 0,0009$ мг/кг). Таку динаміку проникнення кадмію через плацентарний бар'єр i накопичення його в навколоплідних рідинах можна обгрунтовувати тільки здатністю обох частин плаценти до його акумулювання. Проте материнська частина плаценти має вищу здатність до акумулювання, ніж фетальна.

Корок слизу шийки матки $(0,06 \pm 0,01$ мг/кг) містить кадмію стільки ж, як і фетальна частина плаценти $(0,06 \pm 0,009$ мг/кг). Можна припустити, що кадмій з МЧП проникає не тільки в ФЧП, а й у внутрішнє середовище матки, в простір між хоріоном і ендометрієм, звідки абсорбується муцинами корку слизу шийки матки тільних корів. Не виключено, що кадмій через навколоплідні оболонки, насамперед амніотичну і хоріальну, теж проникає у внутрішнє середовище матки i абсорбується муцинами корку слизу шийки матки.

Порівняно 3 контролем $(0,15 \pm 0,02$ мг/кг) згодовувана коровам першої групи суміш сапоніту і сірки сприяло зниженню проникнення кадмію із організму матері до МЧП $(0,16 \pm 0,04$ мг/кг) у 1,1 разу $(\mathrm{P} \geq 0,05)$. Окрім цього, зросла бар'єрна функція МЧП відносно ФЧП $(0,15 \pm 0,02$ і $0,02 \pm 0,008$ мг/кг) порівняно 3 контролем $(0,16 \pm 0,6$ і $0,06 \pm 0,01)$, бо із неї до ФЧП проникало в 7,5 разів менше кадмію, а в контролі лише в 2,7 рази менше. Концентрація $\mathrm{Cd}$ у ФЧП корів першої дослідної групи (0,02 $\pm 0,008$ мг/кг) достовірно нижча, ніж у корів контрольної групи $(0,06 \pm$ $0,01 \mathrm{мг/ \kappa г;} \mathrm{P} \leq 0,05)$.

Порівняно 3 коровами контрольної групи у корів першої дослідної групи, яким згодовували мінеральну суміш, значно зросла регуляторна функція плацентарного бар'єру: у ФЧП $(0,06 \pm 0,1-0,02 \pm 0,008$ мг/кг; $\mathrm{P} \leq 0,05), \operatorname{AMP}(0,008 \pm 0,001-0,003 \pm 0,0002 \mathrm{мг} / к \Gamma ;$ $\mathrm{P} \leq 0,01)$ і АЛР рідинах $(0,007 \pm 0,0009-0,005 \pm$ 0,002 мг/кг) та в коркові слизу шийки матки $(0,06 \pm$ $0,01-0,02 \pm 0,002 \mathrm{мг/ \kappa г;} \mathrm{P} \leq 0,05)$ накопичилось менше кадмію. $€$ всі підстави припустити, що такі зміни відбулись внаслідок абсорбції сапонітом кадмію із організму корів і виділення його в складі фекалій та сечі. 
Таблиця 5

Вміст Cd у досліджуваних субстратах корів під час отеленняз умовно чистій щодо РАЗ території, $\mathrm{M} \pm \mathrm{m}, \mathrm{Mг} / к г$, $\mathrm{n}=5$

\begin{tabular}{lccc}
\hline \multirow{2}{*}{ Досліджувані субстрати } & \multicolumn{3}{c}{ Групи корів } \\
\cline { 2 - 4 } & Контрольна & 1 дослідна & 2 дослідна \\
\hline Карункул (МЧП) & $0,16 \pm 0,04$ & $0,15 \pm 0,02$ & $0,11 \pm 0,03$ \\
Котиледон (ФЧП) & $0,06 \pm 0,01$ & $0,02 \pm 0,008 *$ & $0,02 \pm 0,007-/ *$ \\
Амніотична рідина (АМР) & $0,008 \pm 0,001$ & $0,003 \pm 0,0002 * *$ & $0,008 \pm 0,001 * * * /-$ \\
Алантоїсна рідина (АЛР) & $0,007 \pm 0,0009$ & $0,005 \pm 0,002$ & $0,007 \pm 0,001$ \\
Слиз шийки матки & $0,06 \pm 0,01$ & $0,02 \pm 0,002 *$ & $0,01 \pm 0,0005 * * / * *$ \\
\hline
\end{tabular}

Примітка: * до риски дробу - порівняння результатів із попередньою групою; * після - із контрольною

У корів другої дослідної групи, яким, окрім мінеральної суміші, додатково ін'єкували тканинний препарат, проникність МЧП як плацентарного бар'єра мала певні особливості. У них в МЧП накопичилось найменше кадмію $(0,11 \pm 0,03$ мг/кг) як порівняно 3 контрольною групою $(0,16 \pm 0,04$ мг/кг, $\mathrm{P} \geq 0,05)$, так i 3 першою дослідною групою $(0,15 \pm 0,02$ мг/кг, $\mathrm{P} \geq$ $0,05)$ корів. Із МЧП до ФЧП проникало кадмію у 5,5 разів менше. Вміст його там був аналогічним, як і у корів першої дослідної групи, але меншим, ніж у корів контрольної групи $(\mathrm{P} \leq 0,05)$ (табл. 5).

Із ФЧП до організму плода проникало і накопичувалось у АЛР рідині, порівняно з першою дослідною групою, більше $\mathrm{Cd}(0,005 \pm 0,002-0,007 \pm$ 0,001 мг/кг, $\mathrm{P} \geq 0,05)$, однакова кількість порівняно 3 коровами контрольної групи (табл. 5), а в АМР рідині циркулювало у 2,7 разу більше, ніж у корів першої дослідної групи $(0,008 \pm 0,001$ і $0,003 \pm 0,002$ мГ/кг, $\mathrm{P} \leq 0,001)$.

Концентрація $\mathrm{Cd}$ в коркові слизу шийки матки у корів другої дослідної групи була нижчою, ніж у корів першої дослідної групи $(0,01 \pm 0,0005$ і $0,02 \pm$ $0,002 \mathrm{мг/ \kappa г,} \mathrm{P} \leq 0,01)$ і корів контрольної групи $(0,01 \pm$ $0,0005$ i $0,06 \pm 0,01$ мг/кг, $\mathrm{P} \leq 0,01)$.

Рівень $\mathrm{Pb}$ у тварин контрольної групи в ФЧП $(0,57 \pm 0,19$ мГ/кг), порівняно 3 МЧП $(0,46 \pm$ 0,18 мг/кг), вищий у 1,2 разу (табл. 6). У тварин першої $(0,47 \pm 0,11-0,23 \pm 0,14$ мг/кг) і другої дослідної групи $(0,60 \pm 0,17-0,06 \pm 0,01 \mathrm{мг} / к г)$ він у 2 і 10 разів відповідно більший. В алантоїсній рідині $(0,62 \pm$ 0,16 мг/кг) накопичувалось і циркулювало майже стільки ж свинцю $(0,57 \pm 0,19$ мг/кг), як і в фетальній частині плаценти.

\section{Таблиця 6}

Вміст свинцю в досліджуваних субстратах корів під час отелення із умовно чистій щодо РАЗ території, $\mathrm{M} \pm \mathrm{m}$, $\mathrm{M} \Gamma / \kappa \Gamma, \mathrm{n}=5$

\begin{tabular}{lccc}
\hline \multirow{2}{*}{ Досліджувані субстрати } & \multicolumn{3}{c}{ Групи корів } \\
\cline { 2 - 3 } & Контрольна & 1 дослідна & 2 дослідна \\
\hline Карункул (МЧП) & $0,46 \pm 0,18$ & $0,23 \pm 0,14$ & $0,06 \pm 0,01$ \\
Котиледон (ФЧП) & $0,57 \pm 0,19$ & $0,47 \pm 0,11$ & $0,60 \pm 0,17$ \\
Амніотична рідина (АМР) & $0,52 \pm 0,07$ & $0,38 \pm 0,10$ & $0,18 \pm 0,07-/ * *$ \\
Алантоїсна рідина (АЛР) & $0,62 \pm 0,16$ & $0,16 \pm 0,05 *$ & $0,55 \pm 0,19$ \\
Слиз шийки матки & $1,01 \pm 0,28$ & $2,47 \pm 0,26 *$ & $0,67 \pm 0,06 * /-$ \\
\hline
\end{tabular}

Примітка: * до риски дробу - порівняння результатів із попередньою групою; * після - із контрольною

Під впливом мінеральної добавки помітно підвищувалося проникнення свинцю із АЛР і АМР рідин у внутрішнє середовище матки, звідси він абсорбувався муцинами корка слизу шийки матки і там депонувався $(2,47 \pm 0,26$ мг/кг, $\mathrm{P} \leq 0,001)$. Таким чином, мінеральна добавка до раціону корів у складі сапоніту і сірки сприяла проникності через плацентарний бар'єр свинцю у бік зниження його накопичення в материнській частині плаценти, збільшення в фетальній та коркові слизу шийки матки тільних корів.

Додаткове введення коровам другої дослідної групи тканинного препарату ще в більшій мірі сприяло зниженню бар'єрної здатності МЧПчастини плаценти і підвищенню іiі у ФЧП частині. Так, у них свинцю в МЧП накопичувалось $0,06 \pm 0,01$ мг/кг, у контрольних корів - 0,46 \pm 0,18 мг/кг, у тварин першої дослідної $0,23 \pm 0,13$ мг/кг. У ФЧП концентрація свинцю майже така $(0,60 \pm 0,17$ мг/кг), як у корів контрольної $(0,57 \pm$
0,18 мг/кг) і вища, ніж першої дослідної (0,47 \pm 0,11 мг/кг) групи. Бар'єрна здатність ФЧП частини плаценти порівняно з МЧП під дією тканинного препарату збільшувалась у 10 разів. Свинець накопичувався в ній у майже такій же концентрації, як і в коркові слизу $(0,67 \pm 0,06$ мг/кг).

За відсутності вірогідної різниці у показниках накопичення кадмію в МЧП частині $(0,16 \pm 0,02$ і $0,16 \pm$ 0,04 мГ/кг) і ФЧП $(0,06 \pm 0,006$ і $0,06 \pm 0,01$ мГ/кГ) у корів контрольних груп із умовно чистої і РАЗ зони, його проникнення до плода і циркуляція в організмі значно вища у корів із умовно чистої зони (умовно чиста зона: амніотична рідина $0,07 \pm 0,002$ мг/кг, алантоїсна рідина - 0,04 $\pm 0,002$ мг/кг, корок слизу $0,08 \pm 0,005$ мг/кг; забруднена зона: $0,008 \pm 0,001-$

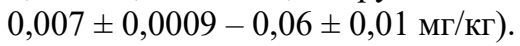

За додаткового введення коровам тканинного препарату фетоплацентат рівень Cd у них в умовах PA3 у 
МЧП знизився порівняно з першою дослідною і контролем, у ФЧП не змінився, в АМР і АЛР - знизився в першій дослідній, в коркові слизу шийки матки теж знизився щодо контролю і першої дослідної групи, а в умовно чистій зоні МЧП зменшився порівняно $з$ дослідною групою і контролем, в ФЧП щодо першої дослідної групи не змінився, контролю - знизився, в AMP і АЛР порівняно з корком слизу шийки матки, також знизився.

Свинець накопичувався в МЧП частині плаценти корів контрольних груп обох господарств в однаковій концентрації $(0,46 \pm 0,18$ мг/кг - зона РАЗ і $0,47 \pm$ 0,17 мг/кг - чиста зона) і проникав із неї до ФЧП частини плаценти та акумулювався в ній в значно вищих концентраціях $(0,57 \pm 0,19$ мг/кг - зона РАЗ і $0,64 \pm$ 0,15 мг/кг - чиста зона). Проте за майже однакових концентрацій свинцю у плаценті, його проникність до АМР та АЛР рідин відрізнялась: в умовно чистій зоні в АЛР рідині він накопичувався у 8 разів $(0,08 \pm$ 0,04 мг/кг) менше, ніж в забрудненій радіонуклідами $(0,62 \pm 0,16$ мг/кг), в AMP майже в 26 разів $(0,02 \pm$ 0,002 мг/кг) порівняно 3 забрудненою $(0,52 \pm$ 0,07 мг/кг), в коркові слизу шийки матки корів з умовно чистої зони його концентрація була в 17 разів нижчою $(0,06 \pm 0,03$ мг/кг), ніж у забрудненій $(1,01 \pm$ 0,28 мг/кг).

Введення коровам тканинного препарату корегувало накопичення свинцю у корів із умовно чистої зони порівняно із забрудненою: в бік зменшення концентрації у МЧП частині плаценти відносно дитячої $(0,05 \pm 0,01$ i $0,27 \pm 0,11-0,06 \pm 0,01$ i $0,60 \pm$ 0,17 мг/кг) та в АМР рідині $(0,015 \pm 0,002$ і $0,18 \pm$ 0,07 мг/кг) в 12 разів; в АЛР рідині $(0,06 \pm 0,02$ і $0,55 \pm$ $0,18)$ та коркові слизу $(0,17 \pm 0,04$ і $0,67 \pm 0,06)$ менше у 8,3 і 3,9 рази відповідно.
У крові кобил у першу стадію жеребіння рівень $\mathrm{Pb}$ у 2 рази $(12,600 \pm 0,005)$ вищий, ніж $\mathrm{Cd}(6,200 \pm$ 0,006), що відображає їх наявність і поступання 3 кормом та водою і метаболізмом в організмі.

В пуповинному канатику порівняно з іншими сустрактами реєструються сліди $\mathrm{Pb}$, а Сd зовсім не депонується. Отже, можемо припустити, що пуповинний канатик $є$ транспортною ділянкою шляху, по якому наявний в крові кобили Сd поступає в печінку плода, де його концентрація в 11 разів вища, ніж $\mathrm{Pb}$, включається в обмінні процеси організму, виділяється із нього в амніотичну та алантоїсну порожнини і накопичується в їх рідинах. Основним шляхом виділення $\mathrm{Cd}$ iз організму плода $є$ нирки, бо в алантоїсній рідині його концентрація найвища (табл. 7).

Вміст $\mathrm{Pb}$ в алантоїсній оболонці в 2,6 разів вищий, ніж в хоріальній (ФЧПК), в 3,7 разу, ніж в алантоїсній рідині, в 4,7 разу, порівняно з амніотичною рідиною.

Водночас в амніотичній рідині $\mathrm{Pb}$ міститься в 1,3 рази менше, ніж у алантоїсній рідині, і майже в 4,2 разу, порівняно з печінкою плода. При цьому в амніотичній рідині депонується $\mathrm{Pb}$ в 24,5 , а в алантоїсній в 31 раз більше, ніж у пуповинному канатику.

Отже, алантоїсна оболонка є не тільки мішком, в порожнині якого накопичується алантоїсна рідина, а й депо акумулювання $\mathrm{Pb}$, що $з$ сечею виводиться в іï порожнину, а з неї абсорбується в алантоїсну оболонку.

Під час жеребіння, порівняно з кров'ю кобил, максимально щодо проникання Рb проявляється бар'єрна функція АОЛ, де його концентрація в 1,8 рази вища. У печінці лошат вона в 1,6 разів вища i, мігруючи в їх організмі, виділяється в амніотичну та алантоїсну рідини, з якої абсорбується алантоїсною оболонкою в концентрації, що в 1,8 разів вища, ніж в крові кобил.

\section{Таблиця 7}

Проникність $\mathrm{Pb}$ і Сd через ПБ під час жеребіння, мкг/кг, $\mathrm{M} \pm \mathrm{m}, \mathrm{мг} / \kappa г, \mathrm{n}=5$

\begin{tabular}{llrc}
\hline \multicolumn{1}{c}{ Субстрат } & $\mathrm{n}$ & \multicolumn{1}{c}{$\mathrm{Pb}$} & $\mathrm{Cd}$ \\
\hline Кров кобил (КК) & 5 & $12,600 \pm 0,005$ & $6,200 \pm 0,006$ \\
Пуповинний канатик (ПКЛ) & 5 & $0,200 \pm 0,009$ & - \\
Хоріон (ФЧПК) & 5 & $8,800 \pm 0,004$ & $0,200 \pm 0,001$ \\
Печінка плода (ППЛ) & 3 & $20,400 \pm 0,004$ & $272,400 \pm 0,013$ \\
Амніотична рідина (АМРЛ) & 5 & $4,900 \pm 0,002$ & $12,600 \pm 0,003$ \\
Алантоїсна рідина (АЛРЛ) & 5 & $6,200 \pm 0,005$ & $33,400 \pm 0,004$ \\
Алантоїсна оболонка (АОЛ) & 5 & $23,100 \pm 0,002$ & $0,200 \pm 0,002$ \\
\hline
\end{tabular}

Можемо припустити, що під час жеребіння бар'єрна функція ПКЛ щодо Сd відсутня, він транзитом проходить через нього до плода, максимально акумулюється в його печінці і мігруючи в організмі накопичується в АМР та АЛР рідинах, з якої виділяється з організму кобил.

Наведені результати досліджень є початком глибинного вивчення функцій ПБ свійських тварин, що дають можливість протягом вагітності запропонувати ефективні способи і засоби корекції проникності поживних речовин із організму матері до плода, змінити його розвиток у бажаному напрямку.

Дослідження стану і функціонування ПБ ссавців, у свійських тварин зокрема, обмежуються окремими фрагментарними повідомленями, не відображають перебігу фізіологічних процесів в окремих ланках ланцюга “мати - плід” та у зворотньому напрямку. Їх доцільно врахувати лише при обговорюванні окремих 
досліджуваних показників. При аналізі отримані результати власних досліджень нами порівняні не лише між собою в динаміці перебігу тільності, а й 3 повідомленнями в літературних джерелах щодо функціонування ПБ за різного фізіологічного і патологічного стану організму жінок. Наш вибір порівняння обгрунтований однаковою тривалістю вагітності в жінок і корів, органогенезу в плодів за час внутрішньоутробного розвитку.

Проникність ПБ корбил під час жеребіння порівняли зі станом проникності $\mathrm{Pb}$ i $\mathrm{Cd}$ через ПБ корів для того, щоб з'ясувати наявність відмінності в тварин за різного типу і зв'язку плацент між обома ії частинами.

Плацента забезпечує зв'язок між організмом матеpi i плода, виступає в ролі бар'єра, але важкі метали проникають через неї і негативно впливають на плід (Zakrzewska at al., 2002; Zasiekin, 2003; Ostrovskaja, 2016; Wang et al., 2016; Xu et al., 2016).

У доступних повідомленнях, опублікованих протягом останніх років, значна увага приділена дослідженні впливу важких металів, кількість яких на 1 км² $^{2}$ в Україні в 6,5 разу більша, ніж у США, і в 3,2 разу, ніж у Європейському економічному союзі, звертається увага на наслідки їх впливу на стан плаценти, ембріона, перебіг вагітності та пологів, стан новонароджених (Ventskivskyi, 2010).

Отже, нагромадившись до певного максимального рівня в МЧП, Сd транзитом проходить через ФЧП, оскільки його концентрація в ній не змінюється, в судини пуповини, з яких, завдяки високій проникності їх стінок, проникає в вартонові драглі, де абсорбується гіалуроновою кислотою, яка є ії головною складовою частиною, далі надходить до печінки плода i мігрує в його організмі.

Як бачимо, функція ПБ щодо $\mathrm{Cd}$ проявляється в максимальному затриманні його в МЧП на 4-5 місцях тільності, стабільно, але майже в 3 рази менше в ФЧП протягом усього періоду тільності. Ці терміни тільності ми визначаємо як критичні рівні ПБ щодо проникності $\mathrm{Cd}$ з організму матері до плода, що узгоджується $з$ поглядом інших авторів (Rosin, 1977; Mishchenko, 1996; Krajneva, 2009; Muhacheva \& Bezel', 2015).

Уміст хімічних елементів у плаценті рудої польовки не залежно від рівня забруднення території, за винятком $\mathrm{Cd}$, концентрація якого в плаценті на забруднених ділянках менша в 6 разів перевищувала фонові значення (Muhacheva \& Bezel', 2015).

Якщо розглядати тільки функцію ПБ, не враховуючи подальшої міграції досліджуваних мікроелементів, то наяву високий прояв бар'єрної функції окремо МЧП і ФЧП.

Дослідження, у яких би висвітлювалася траслокація хімічних елементів в ланцюгу раціон - материнський організм - плацента - плід за їх хронічного впливу на організм тварин в умовах експерименту дуже обмежені, а для природних популяцій практично відсутні (Muhacheva \& Bezel', 2015).

Концентрація кадмію в плаценті може досягти 1,25,3 мг/кг сухої ваги, що вище, ніж у крові і в 100 разів, порівняно з пуповинною кров'ю, корелює позитивно 3 вмістом у крові (Al-Salec, 2015).

Щодо Cd - МЧП потужний бар'єр з боку матері, який затримує його в середині і в кінці тільності, ФЧП - такий же бар'єр з боку плода, але затримує його стабільно протягом усього періоду тільності, максимально збільшуючись при його закінченні.

Дискримінаційна функція плаценти проявляється як частковий бар'єр для $\mathrm{Cd}, \mathrm{a} \mathrm{Pb}$ проникає через неї вільно. В тварин із забруднених ділянок під кінець вагітності $\mathrm{Cd}$ міститься в середньому в 5 разів більше в плаценті, ніж на фонових ділянках, а для $\mathrm{Pb}$ різниці не було виявлено (Muhacheva \& Bezel', 2015).

Проникання $\mathrm{Cd}$ як одного з найтоксичніших і розповсюдженіших в Україні важких металів через плаценту до плода привертає увагу багатьох дослідників, бо він накопичується в його тканинах і викликає зміни їх морфологічної структури і функції.

Вплив Cd на внутрішньоутробний розвиток проявляється порушенням процесів у генах ембріонів, що регулюють опоптоз.

Тривалий пренатальний вплив $\mathrm{Cd}$ негативно відображається на здоров'ї дитини і $є$ причиною багатьох захворювань в дорослих. Його рівень необхідно контролювати в крові матері, 3 профілактичною метою вживати вітамінні добавки (Ostrovskaja, 2016).

Свинець поступово накопичується в біологічних субстратах вагітних, але до певного його рівня адаптивні механізми фетоплацентарного комплексу не порушуються, вміст $\mathrm{Pb}$ в біологічних середовищах системи “мати - плацента - плід” у крові вагітних та пуповинній крові новонароджених різна, що дозволяє припустити про різну бар'єрну функцію плаценти щодо $\mathrm{Pb}$, що плацента не захищає плід від накопичення $\mathrm{Pb}$ в тканинах плода (Ventskivskyi, 2010).

Збільшення рівнів $\mathrm{Pb}$ і в меншій мірі $\mathrm{Cd}$ під кінець внутрішньоутробного періоду в ембріонах рудої полівки супроводжується зниженням їх маси при народженні і виживання після народження (Muhacheva \& Bezel', 2015).

Плацентарний бар'єр обмежує надлишкове поступання $\mathrm{Cu}, \mathrm{Zn}$ i $\mathrm{Cd}$, але через нього легко проникає $\mathrm{Pb}$.

Барьерная функция МЧП относительно $\mathrm{Pb}$ с течением стельности, до ее половины, увеличивается, к завершению - уменьшается.

Тривалий контакт організму вагітних зі шкідливими хімічними речовинам, навіть на рівні порогових і підпорогових значень, приводить до пошкодження фетоплацентарного комплексу з розвитком плацентарної дисфункції і формування внутрішньоутробних дезадаптивних процесів, що реалізують вивчення функціональних можливостей захисних систем, що ся наступним ускладненням вагітності і родів (Fedorova et al., 1994).

Вивчення функціональних можливостей захисних систем, що запобігають надходженню в організм плода шкідливих і метаболічно активних токсикантів $є$ плацента (Hanson et al., 2012; Gel'fond et al., 2014; Biletska \& Onul, 2014). 
За результатами натурних досліджень встановлено, что в умовах техногенних територій біосубстрати системи “мати - плацента - плід” містять абіотічні метали в підвіщених концентраціях, що склало для свинцю 1,3 $\pm 0,11$ мг/кг, для кадмію $0,25 \pm 0,045$ мг/кг, що в 1,4-3,9 разу (Р $\leq 0,01)$ перевищує аналогічні показники для екологічно чисельних територій (Ventskivskyi, 2010; Biletska \& Onul, 2014). Проведене дослідження свідчить про існування динаміки проникності $\mathrm{Cd}$ і $\mathrm{Pb}$ через ПБ корів.

Потужним бар'єром на шляху міграції $\mathrm{Cd}$ i $\mathrm{Pb}$ в організмі плода $є$ вартонові драглі його пуповини.

Концентрація мікроелементів у слизовому корку шийки матки під час отелення відображає абсорбційні властивості муцину, що $є$ його основним компонентом стосовно до продуктів метаболізму, які накопичились у порожнині матки за певний відрізок тільності. Сам факт накопичення мікроелементів у коркові слизу шийки матки тільних корів в концентраціях близьких до тих, що виявлені в амніотичній та алантоїсній рідинах, не тільки підтверджує здатність його до абсорбції, а й вимагає дати відповідь на шляхи міграції речовин у статевих органах. У всіх випадках ми відбирали корок слизу, що виділявся із шийки матки до розриву навкоплідних оболонок і таким чином виключали його контакт із навкоплідними рідинами. Отже, материнська частина плаценти накопичує кадмій і є його потенційним депо, або складом, а фетальна частина - це основний регулятор або власне бар'єр на шляху його проникнення до плода.

При дослідженні вмісту важких металів у біосубстартах вагітних і новонароджених найінформативнішими в Донецькому регіоні $є$ венозна кров вагітних, плацента, пуповинна кров новонароджених, а ксенобіотичними важкими металами - свинець, хром, нікель (Ventskivskyi, 2010). Наявність кадмію в коркові слизу шийки матки свідчить про те, що він проникає у внутрішнє середовище матки із провізорних органів найвірогідніше через стінки алантоїса і амніона.

В Україні проблема вивчення важких металів особливо актуальна, де кількість забруднень, що припадає на 1 км² площі в 6,5 разу більша, ніж у США, в 2,3 разу більша, ніж у Свропейському економічному Союзі.

Є повідомлення про наслідки впливу кадмію, свинцю, хрому і марганцю на розвиток ембріону, перебіг вагітності та родів повідомляє (Mishchenko, 1996; Ventskivskyi, 2010).

Плацента чутлива до впливу хімічних факторів довкілля, в ній накопичується в 1,4-3,9 разу більше ксанобіотиків порівняно з аналогічними показниками екологічно чистих територій. Додаткове навантаження організму жінок $\mathrm{Pb}$ під час вагітності викликає підвищення у 2,4-3,2 разу накопичення його в плаценті і призводить до пошкодження фетоплацентарного комплексу. Експериментально установлено, що на тлі свинцевої інтоксикації включаються адаптивні i бар'єрно-детоксикаційні процеси в плаценті, які проявляються в підвищенні на 45-52\% рівня внутрішньоплацентарної комуляції ксенобіотиків і, як наслідок, зменшення на 10,2-26,2\% рівня їхнього трансплантаційного проходження (Biletska \& Onul, 2014).

Можемо припустити, що під впливом тканинного препарату зросла бар'єрна функція плаценти взагалі щодо проникненя кадмію із організму матері до плода. Якщо порівняти накопичення кадмію в контрольній і в обох дослідних групах корів в напрямку “МЧП $\rightarrow$ ФЧП $\rightarrow$ амніотична $\rightarrow$ алантоїсна рідини $\rightarrow$ корок слизу”, то виявляється аналогічна динаміка зменшення їх в ФЧП і АЛР рідині, зростання в АМР рідині і коркові слизу шийки матки.

Отже, введення тканинного препарату ще більше підвищувало проникність свинцю через бар'єр МЧП частини плаценти, тобто бар'єрна функція МЧП частини плаценти знизилась, але зросла ФЧП частини плаценти. За такого стану плацентарного бар'єру не змінилось накопичення свинцю в АМР рідині порівняно 3 контролем і знизилось порівняно 3 першою дослідною групою, в АЛР рідині - збільшилось порівняно $з$ першою дослідною групою, але зменшилось порівняно з контролем. За такої зміни функції плацентарного бар'єру в значній мірі підвищилась захисна здатність самого плода, що проявилось у майже однаковій видільній функції нирок, як в контролі, в значному накопиченні свинцю в коркові слизу в другій дослідній групі внаслідок зростання його проникнення через навколоплідні оболонки та із організму корів.

Нами установлено, що згодовування коровам в запуску добавки до раціону мінеральної суміші в складі сапоніту та сірки і додаткове введення тканинного препарату сприяло зростанню бар'єрної функції обох частин плаценти і зниженню проникнення кадмію від матері до материнської і фетальної частин плаценти, зменшення концентрації в коркові слизу шийки матки, а згодовування тільки суміші сапоніту і сірки зменшенню вмісту кадмію в амніотичній і алантоїсній рідинах.

Бар'єрна функція плаценти щодо проникнення із організму матері до плода речовин може проявлятись двома способами: перший - це підвищення бар'єрної здатності материнської частини плаценти і акумулювання в ній токсичних речовин, другий - затримання i накопичення речовин в тканинах фетальної частини і у всіх його оболонках (Shtern, 1927; Rosin, 1977; Ventskivskyi, 2010; Biletska \& Onul, 2014).

Проникнення свинцю через плацентарний бар'єр із організму матері до плода, порівняно з кадмієм, має певні особливості, що, напевно, залежить не тільки від стану організму матері та плода, а й від кумулятивних властивостей самого елемента. Вони проявились в обох зонах проведених досліджень як у контрольної, так і дослідних груп корів найперше тим, що порівняно $з$ материнською частиною плаценти бар'єрна функція фетальної їі частини виражається сильніше, бо вона виступає кумулюючою ланкою плацентарного бар'єру.

Результати наших досліджень узгоджуються 3 даними інших авторів, які експериментально установили, що на тлі свинцевої інтоксикації включаються 
адаптивні і бар’єрно-детоксикаційні процеси в плаценті, які проявляються в підвищенні на 45-52\% рівня внутрішньоплацентарної комуляції ксенобіотиків і, як наслідок, зменшення на 10,2-26,2\% рівня їх трансплантаційного проходження (Biletska \& Onul, 2014).

Напевно, за нижчої здатності материнської частини плаценти до затримання отруйних для організму плода речовин функцію захисту бере на себе сам плід через фетальну частину плаценти, що максимально, до певного рівня, накопичує їх і затримує.

На організм вагітної жінки впливає цілий комплекс антропогенних та інших чинників, що проявляється порушенням функції плаценти, розвитком імунопатологічних процесів у плацентарний тканині і органів плода (Zubzhickaja et al., 2015).

Щодо свинцю бар'єрна функція плаценти проявляється в тому, що, проникаючи з материнської частини плаценти $(0,46 \pm 0,18$ мг/кг), він максимально затримується фетальною частиною $(0,57 \pm 0,19$ мг/кг), проникає у внутрішнє середовище матки, звідки абсорбується муцинами корка слизу $(1,01 \pm 0,28$ мг/кг).

Високий рівень $\mathrm{Cd}$ в плаценті і рівень у пуповинній крові новонароджених, нижчий за рівень у крові матері, свідчить про те, що проникність $\mathrm{Cd}$ до плоду $є$ нижчою, ніж свинцю (Ventskivskyi, 2010).

Окрім цього, свинець, що проникає до плода, виділяється в амніотичну рідину $(0,52 \pm 0,07$ мг/кг) і в найбільшій концентрації накопичується в алантоїсній рідині $(0,62 \pm 0,16$ мг/кг). Отже, у корів контрольної групи свинець накопичується в материнській частині до певного рівня, проникає із неї до фетальної частини плаценти і там акумулюється до граничного рівня. Далі він проникає в організм плода та в навколоплідні рідини.

Свинець, що проникає із плаценти і навколоплідних рідин у внутрішнє середовище матки, на нашу думку, адсорбується і накопичується в коркові слизу шийки матки тільних корів. Подібна динаміка проникнення свинцю із крові матері до плода і у корів першої дослідної групи. Під впливом згодовуваної їм суміші сапоніту і сірки бар'єрна здатність материнської частини плаценти значно зменшилась. Свинцю накопичувалося в фетальній частині плаценти $(0,47 \pm$ 0,11 мг/кг) у 2 рази більше, ніж у материнській $(0,23 \pm$ 0,14 мг/кг). В алантоїсній $(0,16 \pm 0,05$ мг/кг) і амніотичній $(0,38 \pm 0,10$ мг/кг) рідинах дослідних тварин свинцю накопичується значно менше порівняно 3 коровами контрольної групи $(0,62 \pm 0,16$ мг/кг; $\mathrm{P} \leq 0,05$ і 0,52 $\pm 0,07$ мг/кг; $\mathrm{P} \geq 0,05$ відповідно).

Таким чином, порівняно з мінеральною добавкою введення коровам тканинного препарату сумісно 3 мінеральною добавкою сприяло значному підвищенню корегувальної проникної здатності свинцю через плацентарний бар'єр. При цьому основною бар'єрною структурою на шляху проникнення свинцю із крові матері до плода $є$ фетальна частина плаценти. У самого плода ця корекція проявляється у більшому накопиченні свинцю в алантоїсній рідині $(0,55 \pm$ 0,18 мг/кг), ніж в амніотичній $(0,18 \pm 0,07$ мг/кг). Тканинний препарат також сприяє збільшенню проник- нення свинцю із плаценти і навколоплідних рідин у внутрішнє середовище матки та абсорбції муцинами корка слизу $(0,67 \pm 0,67$ мг/кг).

Згодовування сапоніту і сірки та введення тканинного препарату по-різному вплинули на проникність плацентарного бар'єру. У корів першої дослідної групи в умовно чистій щодо РАЗ зони після згодовування мінеральної добавки концентрація кадмію в материнській частині плаценти була нижчою $(0,11 \pm$ 0,02 мг/кг), ніж у корів із зони РАЗ $(0,15 \pm 0,02$ мг/кг), i до фетальної частини плаценти проникало кадмію в 5,5 разів менше $(0,11 \pm 0,02-0,02 \pm 0,003$ мг/кг), а в забрудненій - у 7,5 разів менше $(0,15 \pm 0,02-0,02 \pm$ 0,008 мг/кг), тобто проникність кадмію в напрямку материнська $\rightarrow$ фетальна частина плаценти була нижча у тварин із зони РАЗ. Отже, корегуючий вплив мінеральної добавки на проникність плацентарного бар'єру для кадмію проявлявся у чистій відносно РАЗ зоні менше, ніж у забрудненій. Здатність обох частин плаценти накопичувати і затримувати кадмій більш виражена у корів із зони РА3, і тому Cd у них проникав до навколоплідних рідин і накопичувався в них у мізерній концентрації $(0,005 \pm 0,002$ i $0,003 \pm$ 0,0002 мг/кг). Він більше виділявся у внутрішнє середовище матки, звідки абсорбувався муцинами корку слизу, де концентрація кадмію порівняно з навколоплідними водами вища (табл. 5). Отже, застосований тканинний препарат сприяє накопиченню свинцю в навколоплідних рідинах та коркові слизу шийки матки більше в зоні РАЗ, ніж в умовно чистій. Нами встановлено, що свинець проникає від матері до материнської частини плаценти і накопичується там в малих концентраціях в обох зонах, але в зоні РАЗ у вищій концентрації, ніж в умовно чистій. Надалі він переходить до фетальної частини плаценти і акумулюється там у великих концентраціях. Таким чином, фетальна плацента виступає як потужний бар'єр, особливо у корів із зони РАЗ, на шляху проникнення свинцю від матері до плода.

Узагальнюючи результати проведених досліджень, можна зробити висновок про те, що фетальна частина плаценти корів виступає бар'єром для проникнення кадмію і свинцю до організму плода. Згодовування сапоніту і сірки високопродуктивним коровам та введення тканинного препарату корегують проникність плацентарного бар'єру для важких металів.

\section{Висновки}

При вивченні ПБ необхідно розрізняти і оцінювати окремо бар'єрну функцію материнської і фетальної частин плаценти, які в корів виконують карункули та котиледони відповідно. Максимально бар'єрна функція обох частин плаценти відносно $\mathrm{Pb}$ i $\mathrm{Cd}$ проявляється на 4-5 місяцях фізіологічного перебігу тільності, збігається з їх накопиченням у найвищій концентрації в печінці плода. Вартонова драглиста тканина пуповинного канатика абсорбує $\mathrm{Pb}$ i $\mathrm{Cd}$ із крові судин пуповинного канатика та амніотичної рідини протягом всього періоду тільності, але максимально на 3-4 
місяціях $\mathrm{Cd}$, на 4-5 місяцях $\mathrm{Pb}$. Зі збільшенням терміну тільності концентрація $\mathrm{Pb}$ i $\mathrm{Cd}$ в амніотичній рідині зменшується, в алантоїсній - зростає. Вища концентрація $\mathrm{Pb}$ i Cd у вартоновій драглистій тканині пуповини протягом всього періоду тільності, порівняно 3 амніотичною рідиною, вказує на їі захисну функцію щодо плода. Під кінець тільності бар'єрна функція обох частин плацентарного бар'єра проявляється максимально. Дослідження проникності ПБ кобил під час жеребіння показує, що в їх крові концентрація $\mathrm{Pb}$ в 2 рази вища, ніж $\mathrm{Cd}$, пуповинний канатик відіграє транспортну функцію, концентрація Рb у ФЧПК у 44 рази вища, ніж $\mathrm{Cd}$, який транзитом проходить через ФЧПК і в печінці плода накопичується у 18 разів вищій концентрації, ніж Рb. Мігруючи в організмі плода, $\mathrm{Cd}$ акумулюється в амніотичній рідині майже в 3 рази, в алантоїсній - в 5 разів більше і виділяється 3 нею під час жеребіння.

Перспективи подальших досліджень. У перспективі будуть продовжені дослідження проникності плацентарного бар'єру свійських тварин для мікро- i мікроелементів за різного складу раціону та умов утримання.

\section{References}

Al-Salec, J. (2015). Interaction between cadmium (Cd), Selenium (Se) and oxidative stress biomarkers in healthy mothers and its impact on birth anthoropometric measures. Int. J. Hug. Environ. Health, 218(1), 6690. doi: 10.1016/j.ijheh.2014.08.001.

Amaya, E., Gil, F., Freire, C. et al. (2015). Placenta concentratons of heavy metals in a molher - hild Cohort. Environ. Res., 120, 63-70 doi: 10.1016/j.envres.2012.09.009.

Arshavskij, I.A. (1977). Placentarnyj bar'er. Fiziologija gistogematicheskih bar'erov. Medicina, 443-456 (in Russian).

Berglund, M., Larsson, K., Grandér, M., et.al. (2015). Exposure determinants of cadmium in European mothers and their children. Environ Res., 141, 69-76. doi: 10.1016/j.envres.2014.09.042.

Biasek, M., Micolic, A., Secovanik, A. et. al. (2014), Cadmium in placenta - a valualle biomarker exposure during pregnancy in biomedical research. Toxical. Environ. Health. 77(18), 1071-1074 doi: 10.1080/15287394.2014.915779.

Biletska, E.M., \& Onul, N.M. (2014). Translokatsiia mikroelementiv u systemi "Maty-platsenta-plid" u shchuriv pry fiziolohichnii vahitnosti ta za umovy vplyvu svyntsiu. Medychni perspektyvy, 19(3), 4-9. http://nbuv.gov.ua/UJRN/Mp_2014_19_3_3 Ukrainian).

Bonglaisin, J.N., Chelea, M., Tsafack, T.J.J., Lantum, D.N., Djiele, P.N. et al. (2017). Assessment of Haemoglobin Status and Transplacental Transport of Lead and Calcium During Geophagy. J Nutr Disorders Ther, 7, 204. doi:10.4172/2161-0509.1000204.

Chen, Z., Myers, R., Wei, T., et. al. (2014). Placental transfer and concentrations of cadmium, mercury, lead, and selenium in mothers, newborns, and young children. Journal of Exposure Science and Environmental Epidemiology, 24(5), 537-544. doi: 10.1038/jes.2014.26.

Dashkevych, V.S. (1997). Vplyv malykh doz ionizuiuchoho vyprominiuvannia na systemu maty-platsentaplid. PAH, 3, 89-92 (in Ukrainian).

Esteban-Vasallo, M.D., Aragonés, N., Pollan, M., LópezAbente, G., \& Perez-Gomez, B. (2012). Mercury, cadmium and lead levels in human placenta: a systematic review. Environ Health Perspect, 120, 1369-1377. doi: 10.1289/ehp.1204952.

Fedorova, M.V., Laricheva, I.P., \& Milovanov, A.P. (1994). Korrekcija narushenij funkcii fetoplacentarnoj sistemy $\mathrm{u}$ beremennyh $\mathrm{v}$ zone radioaktivnogo zagrjaznenija i ocenka effektivnosti lechebno-profilakticheskih meroprijatij. Ros. vestn. perinatologii i pediatrii, 39(4), 13-15 (in Russian).

Gel'fond, N.E., Starkova, E.V., \& Gruf, V.V. (2014). Obmen makro- i mikrojelementov pri vvedenii svinca i v uslovijah sorbcionnoj korrekcii na fone beremennosti. Medicina i obrazovanie v Sibiri, 2 (in Russian).

Griffiths, S.K., \& Campbell, J.P. (2015). Placental structure, function and drug transfer. Continuing Education in Anaesthesia Critical Care \& Pain, 15(2), 84-89. doi: 10.1093/bjaceaccp/mku013.

Hanson, M.L., Holaskova, I., Elliott, M., et. al. (2012). Prenatal cadmium exposure alters postnatal immune cell development and function. Toxicol Appl Pharmacol, 261(2), 196-203. doi: 10.1016/j.taap.2012.04.002.

Kippler, M., Hoque, A.M.W., \& Raqib, R. (2010). Accumulation of cadmium in human placenta interacts with the transport of micronutrients to the fetus. Toxicol Lett, 192(2), 162-168. doi: 10.1016/j.toxlet.2009.10.018.

Kippler, M., Tofail, F., Gardner, R., Rahman, A., Hamadani, J.D., Bottai, M., \& Vahter M. (2012) Maternal cadmium exposure during pregnancy and size at birth: a prospective cohort study. Environ. Health Perspect., 120(2), 284-289 doi: 10.1289/ ehp. 1103711.

Krajneva, S.V. (2009). Migracija tjazhelyh metallov v sisteme "Pochva - korma - voda - stel'naja korova molozivo" na territorii Juzhnogo Urala. Avtoref. diss. kand. biol. nauk: 03.00.16. Krasnojarsk (in Russian).

Lianos, M.N., \& Ronco, A.M. (2009). Fetal growth restriction is related to placental levels of cadmium, lead and arsenic but not with antioxidant activities. Reproductive Toxicolog, 27(1), 88-92. doi: 10.1016/j.reprotox.2008.11.057.

Lin, C.M., Doyle, P., Wang, D., et. al. (2011). Does prenatal cadmium exposure effect fetal and child growth? Occupational and Environmental Medicine, 68(9), 641-646. doi: 10.1136/oem.2010.059758.

Mishchenko, V.P. (1996). Vmist tsynku, kadmiiu i rtuti v tsilnii krovi ta tkanynakh platsenty. PAH, 5-6, 75-77 (in Ukrainian).

Mokryk, O.M., \& Zadorozhna, T.D. (2006). Morfolohichni osoblyvosti platsentarnoho barieru $\mathrm{u}$ zhinok, radiatsiino oprominenykh $\mathrm{v}$ pre- ta 
pubertatnomu periodakh. Visn. nauk. Doslidzhen, 2, 32-34 (in Ukrainian).

Muhacheva, S.V., \& Bezel', V.S. (2015). Tjazhelye metally $\mathrm{v}$ sisteme mat' - placenta - plod u ryzhej polevki $\mathrm{v}$ uslovijah zagrjaznenija sredy vybrosami medeplavil'nogo kombinata. Jekologija, 6. 444-453. doi: 10.7868/S0367059715060128 (in Russian).

Muoth, C., Aengenheister, L., Kucki, M., Wick, P., \& Buerki-Thurnherr, T. (2016). Nanoparticle transport across the placental barrier: pushing the field forward! Nanomedicine, 11, 8. doi: 10.2217/nnm-2015-0012.

Ni, W., Huang, Y., Wang, X. et al. (2014). Associations of neonatal lead, cadmium, chromium and nickel coexposure with DNA oxidative damage in an electronic waste recycling town. Science of the Total Environment, 472, 354-362. doi: 10.1016/j.scitotenv.2013.11.032.

Olszowski, T., Baranowska-Bosiacka, I., et. al. (2016). Cadmium Concentration in Mother's Blood, Milk, and Newborn's Blood and Its Correlation with Fatty Acids, Anthropometric Characteristics, and Mother's Smoking Status. Biol Trace Elem Res, 174(1), 8-20. doi: 10.1007/s12011-016-0683-6.

Onul, N.M. (2013). Eksperymentalna otsinka embriotoksychnosti svyntsiu yak faktoru malointensyvnoho vplyvu. Tavrych. medyko-biol. vestnik, 16, 1(61), 165-168 (in Ukrainian).

Ostrovskaja, S.S. (2016). Prenatal'noe vozdejstvie kadmija. Biomedical and biosocial anthropology, 27, 196-199 (in Russian).

Qin, J., Zhu, Y., Yin, F., Wang, H., Wang, L., \& Yuan, J. (2018). Placental barrier-on-a-chip: Modeling placental inflammatory responses to bacterial infection. ACS Biomaterials Science \& Engineering, 4(9), 33563363. doi: 10.1021/acsbiomaterials.8b00653.

Röllin, H.B., Kootbodien, T., Channa, K., \& Odland, J. (2015). Prenatal Exposure to Cadmium, Placental Permeability and Birth Outcomes in Coastal Populations of South Africa. PLoS One, 10(11), e0142455. doi: 10.1371/journal.pone.0142455.

Rosin, Ja.A. (1977). Obshhaja harakteristika metodov issledovanija pronicaemosti. Fiziologija gistogematicheskih bar'erov. M.: Nauka, 42-60 (in Russian).

Sanders, A.P., Claus Henn, B., \& Wright, R.O. (2015). Perinatal and childhood exposure to cadmium, manganese, and metal mixtures and effects on cognition and behavior: a review of recent literature. Curr. Environ. Health Rep, 2(3), 284-294. doi: 10.1007/s40572015-0058-8.

Shtern, L.S. (1927). Placentarnyj bar'er. Ginekologija i akusherstvo, 3(1), 17-19 (in Russian).

Sun, H., Chen, W., \& Wang, D. (2014). The effects of prenatal exposure to low-level cadmium, lead and selenium on birth outcomes. Chemosphere, 108, 33-39. doi: 10.1016/j.chemosphere.2014.02.080.

Tekin, D, Kayaaltı, Z., Aliyev, V., \& Söylemezoğlu, T. (2012). The effects of metallothionein 2A polymorphism on placental cadmium accumulation: Is metallothionein a modifiying factor in transfer of micronutrients to the fetus? Appl Toxicol, 32(4), 270275. doi: 10.1002/jat.1661.
Thompson, J., \& Bannigan, J. (2008). Cadmium: Toxic effects on the reproductive system and the embryo. Reprod. Toxicol., 25(3), 304-315. doi: 10.1016/j.reprotox.2008.02.001.

Ventskivskyi, B.M. (2010). Vmist vazhkykh metaliv u biolohichnykh substratakh systemy "maty-platsentaplid" za syndromu zatrymky rozvytku plodu. Liky Ukrainy, 3(12), 38-41. http://www.healthmedix.com/articles/liki_ukr_plus/2010-1011/10BMVZRP.pdf (in Ukrainian).

Vilahur, N., Vahter, M., \& Broberg, K. (2015).The Epigenetic Effects of Prenatal Cadmium Exposure. Curr Environ Health Rep, 2(2), 195-203. doi: 10.1007/s40572-015-0049-9.

Walker, N., Filis, P., Soffientini, U., Bellingham, M., O'Shaughnessy, P.J., \& Fowler, P.A. (2017). Placental Transporter Localization and Expression in the $\mathrm{Hu}-$ man: the importance of species, sex and gestational age differencest. Biology of Reproduction, 96(4), 733-743. doi: 10.1093/biolre/iox012.

Wang, Y., Chen, L., et. al. (2016). Effects of prenatal exposure to cadmium on neurodevelopment of infants in Shandong, China. Environ Pollut, 211, 67-73. doi: 10.1016/j.envpol.2015.12.038.

Xu, L., Ge, J., Huo, X., Zhang, Y., Lau, A.T.Y., \& Xu, X. (2016). Differential proteomic expression of human placenta and fetal development following e-waste lead and cadmium exposure in utero. Sci Total Environ, 15(550), 1163-1170. doi: 10.1016/j.scitotenv.2015.11.084.

Xu, X., Chiung, Y.M., Lu, F., Qiu, S., Ji, M., \& Huo, X. (2015). Associations of cadmium, bisphenol A and polychlorinated biphenyl coexposure in utero with placental gene expression and neonatal outcomes. Reproductive Toxicology, 52, 62-70. doi: 10.1016/j.reprotox.2015.02.004.

Zajceva, N.V., Ulanova, T.S., \& Morozova, Ja.S. (2002). Svinec v sisteme mat'-novorozhdennyj kak indikator opasnosti himicheskoj nagruzki v regionah jekologicheskogo neblagopoluchija. Gigiena i sanitarija, 4, 45-46 (in Russian).

Zakrzewska, M., Bialoriska, D., \& Sawicka-Kapusta, K. (2002). Cadmium accumulation in fetus and placenta of bank voles (Clethrionomys glareolus). Bull. Environ. Contam., 69, 829-834. doi: 10.1007/s00128002-0134-2.

Zasiekin, D.A. (2003). Rol platsentarnoho bariera pry mihratsii vazhkykh metaliv $\mathrm{z}$ orhanizmu korovymateri do plodu. Veterynarna medytsyna Ukrainy, 8, 40-41 (in Ukrainian).

Zelinskyi, O.O., \& Mishchenko, V.P. (1996). Kontsentratsiia svyntsiu $\mathrm{V}$ systemi maty-platsentaplid. PAH, 5-6, 74-75 (in Ukrainian).

Zubzhickaja, L.B., Kosheleva, N.G., Shapovalova, E.A., Arzhanova, O.N., Dymarskaja, Ju.R., Lavrova, O.V., Semenova, T.V., \& Stolpner, Je.G. (2015). Osobennosti sostojanija placentarnogo bar'era zhenshhin pri vlijanii jekzogennyh i jendogennyh faktorov. Zhurnal akusherstva i zhenskih boleznej, LXIV(5), 36-47 (in Russian). 